\title{
Whatever It Takes: The Real Effects of Unconventional Monetary Policy
}

\author{
Viral V. Acharya \\ Reserve Bank of India
}

\section{Tim Eisert}

Erasmus University Rotterdam

\section{Christian Eufinger}

IESE Business School

\section{Christian Hirsch}

\section{Deutsche Bundesbank}

\begin{abstract}
Launched in Summer 2012, the European Central Bank's (ECB) Outright Monetary Transactions (OMT) program indirectly recapitalized European banks through its positive impact on periphery sovereign bonds. However, the stability reestablished in the banking sector did not fully translate into economic growth. We document zombie lending by banks that remained weakly capitalized even post-OMT. In turn, firms receiving loans used these funds not to undertake real economic activity, such as employment and investment, but to build cash reserves. Creditworthy firms in industries with a high zombie firm prevalence significantly suffered from this credit misallocation, which further slowed the economic recovery. (JEL G20, E44, E58)
\end{abstract}

Received March 21, 2018; editorial decision November 13, 2018 by Editor Philip Strahan. Authors have furnished an Internet Appendix, which is available on the Oxford University Press Web site next to the link to the final published paper online.

We thank our editor Philip Strahan and two anonymous referees for helpful comments. We also appreciate helpful comments from Sumit Agarwal, Taylor Begley, Tobias Berg, Fabrizio Coricelli, Matteo Crosignani, Ruediger Fahlenbrach, Artashes Karapetyan, Luc Laeven, Chen Lin, Marco Di Maggio, Steven Ongena, Jose-Luis Peydro, Saverio Simonelli, David Sraer, Sascha Steffen, Marti Subrahmanyam, and Annette Vissing-Jorgensen. Furthermore, we thank conference participants at the 2017 Conference on "Banks, Systemic Risk, Measurement and Mitigation," the Third Conference on Sovereign Bond Markets, the Sixteenth Jacques Polak Annual Research Conference, NBER AP Meeting 2016, WFA 2017, AFA 2018, the CEPR/RELTIF Meetings in Milan and Capri, the EFA 2016, the MadBar workshop 2016, the 3rd LBS Conference on Syndicated Loans, IF2016 Annual Conference in International Finance, the 4th ABFER Annual Conference 2016, as well as seminar participants at Utah, Austin, Rutgers, the European Central Bank, Rotterdam, Leuven, the Austrian Central Bank, University of South Carolina, Amsterdam, Lausanne, and Frankfurt. This paper has been developed through CEPR's Restarting European Long-Term Investment Finance (RELTIF) Programme, which is funded by Emittenti Titoli. Moreover, this work was supported by the Friedrich-Flick Foerderstiftung and the Fondation Banque de France. C. E. gratefully acknowledges financial support from the Ministry of Economy and Competitiveness (ECO201563711-P) (MINECO/FEDER, UE) and support from the Europlace Institute of Finance (EIF) and the Labex Louis Bachelier. The views expressed in this paper are solely those of the authors and should not be interpreted as reflecting the views of the Reserve Bank of India or the Deutsche Bundesbank. Supplementary data can be found on The Review of Financial Studies Web site. Send correspondence to Tim Eisert, Erasmus University, PO Box 1738, 3000 DR Rotterdam, The Netherlands; telephone (+31) 104081428. E-mail: eisert@ese.eur.nl.

(C) The Authors 2019. Published by Oxford University Press. This is an Open Access article distributed under the terms of the Creative Commons Attribution Non-Commercial License

(http://creativecommons.org/licenses/by-nc/4.0/), which permits non-commercial re-use, distribution, and reproduction in any medium, provided the original work is properly cited. For commercial re-use, please contact journals.permissions@oup.com 
At the peak of the European debt crisis in 2012, the anxiety about excessive sovereign debt led to a spike in government bond yields for countries in the European periphery that was considered unsustainable and endangered the eurozone as a whole. In response, the president of the European Central Bank (ECB), Mario Draghi, introduced the Outright Monetary Transactions (OMT) program by stating on July 26, 2012, during a conference in London that " $[$.... the ECB is ready to do whatever it takes to preserve the euro. And believe me, it will be enough."1 Once activated toward a specific country, the OMT program allows the ECB to buy a theoretically unlimited amount of the country's government bonds in secondary markets. Even though the OMT program has not been activated yet, the sole announcement of its introduction has lowered spreads of sovereign bonds issued by the distressed European countries. The resultant appreciation in bond prices led to a "stealth recapitalization" (a term coined by Brunnermeier and Sannikov 2016) as banks with significant holdings of these bonds experienced large windfall gains, which helped to restore the stability of the European banking system. ${ }^{2}$

Yet, when Mario Draghi reflected on the impact of the OMT program on the real economy during a speech in November 2014, he noted that " [...] these positive developments in the financial sphere have not transferred fully into the economic sphere. The economic situation in the euro area remains difficult. The euro area exited recession in the second quarter of 2013, but underlying growth momentum remains weak. Unemployment is only falling very slowly. And confidence in our overall economic prospects is fragile and easily disrupted, feeding into low investment."3

No evidence conclusively explains why the regained financial stability of the European banking sector did not result in a more robust economic recovery. However, several signs suggest that Europe's weak economic recovery may be a repeat of Japan's “zombie lending” experience in the 1990s. ${ }^{4}$ In 2013, in Portugal, Spain, and Italy, 50\%, 40\%, and 30\% of debt, respectively, was owed by firms which were not able to cover their interest expenses out of their pretax earnings. ${ }^{5}$ In these same countries, about $12 \%, 8 \%$, and $18 \%$ of total bank loans in 2014, respectively, were nonperforming according to data from the World Bank.

\footnotetext{
1 See ECB (2012).

2 Brunnermeier and Sannikov (2016) present a model in which the central bank can recapitalize banks through open market operations and capital gains.

3 See ECB (2014).

4 See, for example, Economist (2013a) and Stothard (2013).

5 See Economist (2013b).
} 
To the best of our knowledge, our paper is the first to provide systematic evidence that, indeed, Europe's slow economic recovery can be at least partially explained by zombie lending of banks that regained some lending capacity after the OMT announcement but which still remained weakly capitalized post-OMT. Similar to the behavior of weakly capitalized Japanese banks during Japan's banking crisis (see, e.g., Giannetti and Simonov 2013), these banks extended new (subsidized) loans at advantageous conditions to provide their impaired borrowers with the liquidity necessary to meet payments on other outstanding loans. Thereby, these banks avoided (or at least deferred) realizing immediate loan losses in the hope that the respective borrowers would eventually regain solvency.

Our results show that roughly $8 \%$ of the loans extended to the firms in our sample in the post-OMT period were such zombie loans. This shift in loan supply away from creditworthy productive firms toward distressed and less productive borrowers led to an inefficient credit allocation, which distorted market competition and caused detrimental effects on employment, investment, and growth. We find that the zombie lending problem was most pronounced in Italy, Spain, and Portugal, where affected industries experienced an investment loss corresponding to on average 1.5 years of investment capital and an on average 7 pp lower employment growth.

Hence, while the policy debate centers around the concern that the liquidity injections into the banking system are not resulting in positive real effects due to the banks' unwillingness to lend, we document another reason for the ineffectiveness of these measures: credit is not allocated to the productive part of the economy. Therefore, while the OMT program probably averted an even fiercer economic downturn (or even a breakup of the eurozone), combining it with a targeted recapitalization measure and/or forced bank closures could have led to a more stable recovery.

For our analysis, we obtain bank-firm relationships from Thomson Reuters DealScan, firm-specific information from the Amadeus database, and bankspecific information from various sources, including banks' credit default swap (CDS) spreads, balance sheet information, and detailed data about banks' sovereign debt holdings from the European Banking Authority (EBA). The sample includes all EU firms from countries for which DealScan provides loan information and covers the years 2009 until 2014. This data set allows us to trace the impact of the OMT announcement through the banking sector to the real economy. Accordingly, we organize our empirical analysis into three parts. First, we determine the extent to which individual banks were affected by the OMT announcement. Second, we track the resultant change in their lending behavior. Third, we evaluate whether the change in loan supply led to financial and real effects for European firms and analyze the subsequent consequences for the banks' loan portfolio performance.

Our results show that banks with significant holdings of bonds issued by stressed European countries (the GIIPS countries, i.e., Greece, Ireland, Italy, 
Portugal, and Spain) realized the highest windfall gains post-OMT, which improved their capitalization. In particular, the equity of banks incorporated in GIIPS countries (GIIPS banks) increased on average by $8 \%$, while it increased by roughly $1 \%$ for non-GIIPS banks. This improvement in the banks' financial health led to an increased loan supply post-OMT. By employing an approach similar to Khwaja and Mian (2008) to control for credit demand, we find that banks with higher windfall gains on their sovereign debt holdings increased their loan supply relatively more than banks with lower windfall gains. While this macro-evidence on bank lending may suggest a healthy restoration of bank credit supply post-OMT, the micro-evidence about which firms received the credit paints a different picture.

To analyze which type of borrowers benefited most from an increased lending volume post-OMT, we divide our sample into low- and high-quality borrowers based on their ability to service existing debt, that is, their EBIT interest coverage ratio (IC). We find that the additional loan supply was mainly targeted toward preexisting low-quality borrowers (i.e., an increase in lending at the intensive margin), but not toward new borrowers (i.e., no increase at the extensive margin).

This finding is consistent with both, the firm balance sheet channel and zombie lending. The firm balance sheet channel involves a positive shock on the credit quality of the borrower pool (e.g., Bernanke and Gertler 1995), which makes lending to low-quality borrowers at appropriately priced loan rates again a profitable investment due to the borrowers' greater net worth, higher collateral value, and better future prospects. In contrast, zombie lending is subsidized lending at advantageous interest rates to economically failed existing borrowers to avoid (or at least defer) loan defaults (e.g., Caballero, Hoshi, and Kashyap 2008).

We use these distinguishing features to determine which channel triggered the banks' credit supply increase to low-quality borrowers post-OMT. First, we show that these loans were given at subsidized interest rates, which is a strong indication for zombie lending. Second, we track the borrowers' financial and real outcomes pre- and post-OMT and document that firm performance of lowquality firms remained poor after they regained access to bank financing. This finding suggests that their weak performance pre-OMT was due to fundamental economic problems and not due to temporary financial constraints, which provides further evidence in favor of zombie lending.

To detect subsidized zombie lending, we follow Caballero, Hoshi, and Kashyap (2008) and Giannetti and Simonov (2013) and check whether distressed firms obtained loans at below-market interest rates, that is, at rates below the rates paid by the most creditworthy firms in the economy (i.e., AAA-rated public firms from non-GIIPS European countries). Our results show that banks that regained some lending capacity post-OMT but still remained weakly capitalized indeed primarily extended subsidized loans to low-quality 
borrowers with whom they had a preexisting lending relationship. For wellcapitalized banks, we find the exact opposite behavior. These banks significantly increased the loan supply to healthy borrowers post-OMT and reduced their zombie lending activity relative to their nonzombie lending.

The documented subsidized zombie lending has three potential explanations: (1) risk-shifting by weakly capitalized banks due to the fear of increasing regulatory scrutiny, (2) pressure to engage in zombie lending by the domestic government (moral suasion) that fears an increase in firm defaults, unemployment rates, and voter dissatisfaction, and (3) a post-OMT clearance of a credit backlog to low-quality GIIPS firms by weakly capitalized GIIPS banks. To separate these three explanations, we document that (1) zombie lending was not prevalent for banks with a significant government ownership stake, (2) did not occur more toward government-owned firms, and (3) also occurred to nondomestic firms and by non-GIIPS banks. These findings suggest that banks' risk-shifting incentives seem to have been the driver of the documented zombie lending.

To further distinguish between subsidized zombie lending and the firm balance sheet channel as explanation for the loan supply increase toward lowquality borrowers, we track the firms' financial and real outcomes pre- and post-OMT. For this analysis, we closely follow Acharya et al. (2018). Our results show that nonzombie firms connected to banks that benefited from the OMT announcement increased their leverage and cash holdings by roughly the same amount. This finding suggests that these firms used the majority of the new loans to build cash reserves. Consistent with this evidence, we do not find any changes in real economic activity for nonzombie firms: investment, employment, and return on assets are not significantly affected by a firm's indirect OMT windfall gains (i.e., the benefits accrued via its banks).

For zombie firms, we find a more pronounced increase in leverage than in cash holdings as these firms had to use the liquidity from new loans, at least partially, to repay other outstanding debt. Accordingly, we also do not find any real effects for zombie firms. This evidence suggests that these firms had fundamental economic problems and did not only suffer from temporary financial constraints, which confirms that the banks' lending behavior was driven by zombie lending incentives and not by improved economic prospects of their borrower pool.

To explore the long-run effects of zombie lending for borrowing firms, we compare the default propensity of zombie versus nonzombie firms. We find that, while zombie and nonzombie firms had similar default rates in the 2 years after the OMT announcement (i.e., 2013 and 2014), zombie firms experienced a sharp increase in default rates from 2015 onward. By 2016, around 15\% of zombie firms in our sample had defaulted compared to only $7.5 \%$ of nonzombie firms. Hence, while zombie lending was initially successful in that it kept these borrowers alive, in the long-run many zombie firms failed anyway because of their significant lower firm quality. 
Regarding the long-run effects for banks that we identify as zombie lending banks based on our syndicated loan data, we find that these banks not only incurred higher losses on their syndicated loans, but across all loan categories (loans to SMEs, etc.). In particular, the ratio of nonperforming loans (NPLs) relative to total loans increased significantly more for zombie lending banks compared to banks for which we do not find evidence for zombie lending over our sample period.

In a final step, we analyze whether the "rise of the zombies" post-OMT had negative spillover effects on nonzombie firms, which could occur via two mechanisms: (1) zombie lending banks shift their loan supply to distressed borrowers, thereby crowding-out credit to productive firms, and (2) zombie firms are kept artificially alive, which distorts market competition (e.g., depressed product prices and higher wages) and thus negatively affects healthy firms competing in the same industries.

Building on the approach of Caballero, Hoshi, and Kashyap (2008), we document that nonzombie firms indeed suffered from an increased zombie presence in their industry: both their investment and employment growth were significantly lower compared to nonzombie firms active in industries without a high zombie prevalence. For example, nonzombie firms in industries with an average increase (i.e., 7 percentage points (pp) increase), in the fraction of zombies invested $12.5 \%$ of capital less and had 5.5 pp lower employment growth compared to a scenario where the zombie prevalence would have stayed at its pre-OMT level.

\section{Related Literature}

Our paper contributes to the small but growing literature that studies the effects of a "stealth recapitalization" (i.e., an indirect recapitalization through a price appreciation of bank security holdings; see Brunnermeier and Sannikov 2016) on bank lending. The OMT announcement is an interesting testing ground for this research question as the crude recapitalization effect of the OMT announcement led to a large heterogeneity in terms of the banks' equity gains and their post-recapitalization equity ratio. 6

So far, most studies on the effect of a stealth recapitalization on bank lending focus on the recent U.S. quantitative easing (QE) programs, which recapitalized banks due to the implemented large-scale asset purchases (LSAPs) and their resultant positive price effect on banks' security holdings. Kandrac and Schlusche (2016) show that bank reserves created by the U.S. QE programs led to higher loan growth and increased bank risk-taking. Di Maggio, Kermani, and Palmer (2016) find that banks originated more mortgages of the type eligible for purchase by the Federal Reserve in response to the LSAPs launch.

6 See Altavilla, Giannone, and Lenza (2014), Szczerbowicz (2015), and Krishnamurthy et al. (2018) for evidence on the impact of the OMT announcement on government bond spreads and prices. 
Rodnyansky and Darmouni (2017) show that banks with a large exposure to the LSAPs, measured by their mortgage-backed securities (MBS) holdings, increased their loan supply more. Chakraborty, Goldstein, and MacKinlay (2016) present evidence that, while banks that benefited from MBS purchases increased lending more than other banks, they decreased their supply of loan types that were not directly targeted by the MBS purchases, which led to a crowding out of commercial lending.

While, as we show, the OMT program also positively affected overall loan growth (see also Ferrando, Popov, and Udell forthcoming, who provide surveybased evidence for an easing of SME credit standards), it did not lead to a crowding-out of noneligible loan types as its recapitalization effect was not due to actual asset purchases but merely its announcement effect. However, our paper highlights that a stealth recapitalization measure can lead to another severe distortion: credit misallocation due to zombie lending. In particular, we show that if such a measure fails to adequately recapitalize (some) banks, this creates incentives to shift loan supply from high- to low-quality borrowers, with detrimental aggregate effects on employment, investment, and economic growth. Hence, while a stealth recapitalization creates less moral hazard ex ante compared to an explicit bailout regime (its crude recapitalization effect is not conditional on being a weak bank, as argued by Brunnermeier and Sannikov 2016), our paper shows that such a nontailored measure creates a strong moralhazard problem ex post as affected banks gain lending capacity, but some might remain undercapitalized.

Our paper is also related to the literature that analyzes the impact of explicit bailouts on bank lending, whose findings are mixed and often conflicting. Regarding the effect of the U.S. Troubled Asset Relief Program (TARP) on lending, Li (2013) and Berger, Makaew, and Roman (forthcoming) find that TARP banks expanded their credit supply, Lin, Liu, and Srinivasan (2014) find a decline in lending, while Duchin and Sosyura (2014) and Bassett, Demiralp, and Lloyd (forthcoming) do not find a change in loan supply. Black and Hazelwood (2013) find mixed results depending on bank size, that is, a loan volume decrease for large TARP banks and no significant change for small TARP banks. ${ }^{7}$

Using German data from 1999 to 2009, Berger et al. (2016) find that bailouts lead to a reduction in lending and risk-taking. For an international sample, Brei, Gambacorta, and Von Peter (2013) find that rescue measures lead to a loan supply increase, but only if a rescued bank's capitalization exceeds a certain threshold. This evidence is also in line with the experience from the Japanese banking crisis in the 1990s (e.g., Peek and Rosengreen 2005). ${ }^{8}$ Consistent with our findings, Giannetti and Simonov (2013) show that Japanese banks

7 Regarding the effect of TARP on credit risk, Duchin and Sosyura (2014) and Berger, Makaew, and Roman (forthcoming) find that TARP banks granted riskier loans post-bailout, whereas $\mathrm{Li}$ (2013) finds no change in loan quality. Black and Hazelwood (2013) find an increase (decrease) in credit risk for large (small) TARP banks.

8 See Kane (1989) for zombie lending evidence in the context of the U.S. savings and loans debacle. 
that remained weakly capitalized even after being bailed out started to engage in zombie lending. Ultimately, this led to a credit misallocation and a long stagnation (see Caballero, Hoshi, and Kashyap 2008).

While the evidence on the effect of bailouts on loan supply is mixed, studies that analyze the impact of capital regulation on lending mostly show that higher capital requirements decrease the loan supply (Aiyar et al. 2014; Aiyar, Calomiris, and Wieladek 2014; Aiyar, Calomiris, and Wieladek 2016; Jiménez et al. 2017; Gropp et al. forthcoming). Blattner, Farinha, and Rebelo (2017) refine these findings by showing that in response to tighter capital requirements affected banks cut back credit for all but a subset of impaired firms for which banks had been underreporting incurred loan losses.

Our paper also contributes to studies that analyze the ECB's liquidity injections. Acharya et al. (2015a) investigate the impact of the ECB's competitive liquidity tender at the beginning of the 2007-2008 financial crisis and find a differential liquidity transmission of low- versus high-risk banks, and an impaired transmission to borrowers of high-risk banks. Using Italian data, Carpinelli and Crosignani (2017) show that while the ECB's Long Term Refinancing Operations (LTRO) helped to limit the bank lending contraction, the loan supply nevertheless decreased post-LTRO as banks used most of the liquidity to buy government bonds (see also Crosignani, Faria-e Castro, and Fonseca 2015). Using country level data on LTRO uptakes, Daetz et al. (2016) find that debt holdings of public firms in countries with a larger share of LTRO uptakes as a fraction of GDP increased in the aftermath of LTRO.

More broadly, our paper also relates to the literature examining the impact of traditional monetary policy on the economy through the bank lending channel. ${ }^{9}$ The recent part of this literature analyzes the link between negative interest rates and bank risk-taking (Heider, Saidi, and Schepens forthcoming), the effect of lower interest rates on bank behavior (e.g., Maddaloni and Peydró 2011; Jiménez et al. 2014; Dell'Ariccia, Laeven, and Marquez 2014), and the passthrough to consumer credit (Agarwal et al. 2017).

\section{Data}

Our data set contains bank-firm relationships in Europe, along with firm and bank-specific information. Information about bank-firm relationships are taken from Thomson Reuters LPC's DealScan, which provides a comprehensive coverage of the European syndicated loan market. In contrast with U.S. firms, European firms use bank financing as the key funding source as only very few bonds are issued in Europe (Standard \& Poor's 2010). Our sample period spans the fiscal years 2009-2014. ${ }^{10}$ Consistent with the literature (e.g., Sufi 2007), all loans are aggregated to a bank's parent.

\footnotetext{
9 See Rodnyansky and Darmouni (2017) for a comprehensive overview of this literature.

10 All our results continue to hold if we drop 2014 from the sample. Results are available on request.
} 
We obtain information on bank and sovereign CDS spreads from Markit, sovereign bond information (i.e., prices, yields, durations, and maturities) from DataStream, bank balance sheet data from SNL, and data on the banks' complete breakdown of sovereign debt holdings from the EBA at the closest date available before July 26, 2012 (the first OMT announcement date), which is the EBA's capital exercise from June 2012.

For banks to be included in the sample, they must act as loan syndicate lead arranger during our sample period. We identify the lead arranger according to definitions in Standard \& Poor's Guide to the European loan market (2010). That is, we classify a bank as a lead arranger if its role is either "mandated lead arranger," "mandated arranger," or "bookrunner." Moreover, the banks need to be included in the capital exercise conducted by the EBA in June 2012. According to the EBA, the sample of banks included in the stress tests cover about $65 \%$ of bank assets in Europe.

Finally, we augment our data set with firm-level accounting data taken from Bureau van Dijk's Amadeus database. Acharya et al. (2018) verify that firms in the intersection of DealScan and Amadeus are comparable to other large firms in Amadeus.

Table 1 provides an overview over the key variables used in the analysis.

\section{Bank Capitalization and Lending}

\subsection{Bank capitalization}

The OMT announcement significantly lowered spreads of sovereign bonds issued by distressed European countries, thereby increasing these bonds' prices (see Altavilla, Giannone, and Lenza 2014; Szczerbowicz 2015; Krishnamurthy et al. 2018). As a result, banks with significant holdings of these bonds experienced substantial windfall gains. First, bonds in the banks' trading book, which are marked-to-market, directly increased in value. Second, even though the sovereign bonds in the banks' banking book are not marked-to-market, investors included a value increase of these bonds in their bank valuation. For example, Italian-based UBI Banca states in its 2012 annual report: "The effects of the narrowing of the BTP/Bund spread entailed an improvement in the market value of debt instruments with a relative positive net impact on the fair value reserve of $855 \mathrm{mn}$ Euro." 11 Given UBI Banca's total equity of 9.8 billion Euro in December 2011, this amounts to a gain of $8.6 \%$.

To formally estimate the impact of the OMT announcement on the banks' capitalization, we use data on their sovereign debt holdings provided by the EBA and the changes in sovereign bond prices to construct a variable called $O M T$ windfall gain that measures how much a bank's equity increased due to

11 See UBI Banca (2012). Consistent with this statement, Acharya, Pierret, and Steffen (2015b) and Krishnamurthy et al. (2018) document significantly positive effects on banks' equity prices after the OMT announcement. 
Table 1

Variable definitions

Variable

Definition

Bank-level key explanatory variables

OMT windfall gain

Weakly capitalized

High-gain

PostOMT

Zombie

$\triangle$ Value EU sovereign debt/Total equity

Dummy equal to 1 if a bank is within $2 \%$ of EBA's regulatory capital requirement

Dummy equal to 1 if a bank has an above mean $O M T$ windfall gain

Dummy equal to 1 if observation falls into the post-OMT period, which starts end of fiscal year 2012

Dummy equal to 1 if (1) a firm received subsidized credit, (2) a firm's rating is $\mathrm{BB}$ or lower, and (3) its syndicate has already provided a loan

\section{Bank-level dependent variables}

\begin{tabular}{|c|c|}
\hline $\begin{array}{l}\Delta \text { Volume } \\
\text { New loan }\end{array}$ & $\begin{array}{l}\ln \left(\text { Volume }_{t+1}\right)-\ln \left(\text { Volume }_{t}\right) \\
\text { Dummy equal to one if the bank issued a new loan to a firm cluster to } \\
\quad \text { which no relation existed pre-OMT }\end{array}$ \\
\hline \multicolumn{2}{|l|}{ Firm-level key explanatory variables } \\
\hline $\begin{array}{l}\text { Average OMT windfall gain } \\
\text { Indirect } O M T \text { windfall gain } \\
\text { Industry frac zombie }\end{array}$ & $\begin{array}{l}\text { Average } O M T \text { windfall gain of all lead arrangers in a given syndicate } \\
\text { Proxy for the extent to which a firm benefited from the OMT } \\
\text { announcement through their banking relationships } \\
\text { Asset-weighted fraction of zombie firms in a given industry and } \\
\text { country in a given year }\end{array}$ \\
\hline \multicolumn{2}{|l|}{ Firm-level dependent variables } \\
\hline $\begin{array}{l}\triangle \text { Debt } \\
\triangle \text { Cash } \\
\text { Employment growth (Emp. growth) } \\
\text { CAPX } \\
\text { Return on assets (ROA) } \\
\text { Productivity } \\
\text { Interest payment (Int. payment) }\end{array}$ & 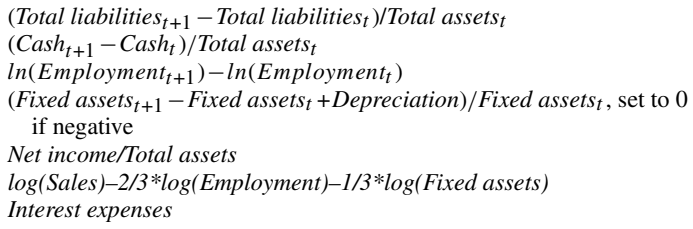 \\
\hline \multicolumn{2}{|l|}{ Firm-level control variables } \\
\hline $\begin{array}{l}\ln (\text { Assets }) \\
\text { Leverage } \\
\text { Net worth } \\
\text { Tangibility } \\
\text { Interest coverage ratio }(I C) \\
\text { EBITDA/Assets }\end{array}$ & $\begin{array}{l}\text { Natural logarithm of total assets } \\
\text { (Total assets - Total equity)/Total assets } \\
\text { (Total shareholder funds \&Liabilities } \\
\quad-\text { Current\&Noncurrent liabilities }- \text { Cash)/Total assets } \\
\text { Fixed assets/Total assets } \\
\text { EBIT/Interest expense } \\
\text { EBITDA/Total assets }\end{array}$ \\
\hline
\end{tabular}

the OMT announcement. ${ }^{12}$ First, we calculate the change in bond prices for all maturities around the three OMT announcement dates (July 26, August 2, and September 6 of 2012) and sum these changes across the three dates. ${ }^{13}$ Next, we multiply the respective sovereign debt holdings outstanding before July 26 and the cumulated change in sovereign bond prices for each maturity and

12 Like Krishnamurthy et al. (2018), we are not able to use Greek and Irish sovereign yields, which are partially or completely missing. Hence, we are not able to calculate the OMT windfall gain for Greek and Irish banks, because the majority of these banks' sovereign debt holdings is domestic.

13 For the OMT announcement dates, we follow Krishnamurthy et al. (2018) and analyze the events on July 26, 2012 ("whatever-it-takes" speech); August 8, 2012 (OMT announcement); and September 6, 2012 (release of technical details). 
country. Finally, the total OMT windfall gain of a bank follows from summing the individual value gains over all EU sovereign bond holdings in the bank's portfolio.

We report this gain on sovereign debt holdings as a fraction of a bank's total equity (measured at the end of fiscal year 2011), that is, we define the windfall gains of bank $b$ as

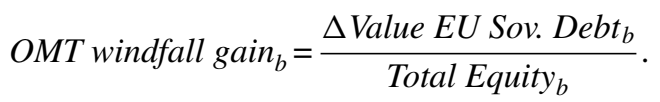

Column 1 of panel A in Table 2 shows that both GIIPS and non-GIIPS banks experienced $O M T$ windfall gains, that is, these banks' equity increased postOMT by $8 \%$ and $1 \%$, respectively. ${ }^{14}$ GIIPS banks had significantly higher gains than did non-GIIPS banks because of their larger GIIPS sovereign bond holdings ( $11.8 \%$ vs. $1 \%$ of total assets, respectively, as shown in Column 2). ${ }^{15}$ Moreover, following Veronesi and Zingales (2010), we show in the Online Appendix that, in addition to the OMT announcement's recapitalization effect, it also freed up liquidity.

Finally, Column 3 reports results for time-series regressions of CDS spreads of each bank on a set of dummy variables for the three OMT announcement dates. We report the mean of the sum of the coefficients over the three dates separately for GIIPS and non-GIIPS banks. In line with the previous findings, the results show that the OMT announcement had a significant positive effect on the perceived stability of GIIPS banks as their CDS spread decreased on average by $96 \mathrm{bp}$, while it decreased on average by 23 bp for non-GIIPS banks. ${ }^{16}$

Taken together, this evidence shows that the OMT announcement led to a stealth recapitalization of European banks (especially GIIPS banks) and thereby reduced the banks' credit risk. In the following, we will refer to banks that strongly benefited from the OMT announcement (above mean OMT windfall gain, which consists mainly of GIIPS banks) as high-gain banks and banks that benefited less (below mean OMT windfall gain) as low-gain banks. ${ }^{17}$

Next, we investigate whether banks became uniformly well capitalized as a result of the stealth recapitalization. Table 2, panel B, presents the evolution of the banks' book leverage ratio separately for high- and low-gain banks and, as a benchmark, also for U.S. banks. Moreover, we present the evolution of the leverage of high-gain banks separately for banks that are within $2 \%$ and above

14 Crosignani, Faria-e Castro, and Fonseca (2015) find similar magnitudes ( $+7.2 \%$ of total equity due to gains from LTRO and OMT).

15 The difference in pre-OMT GIIPS sovereign holdings between GIIPS and non-GIIPS banks can be explained by the banks' home bias (e.g., Acharya and Steffen 2015).

16 Consistent with this finding, Figure A1, panel A, shows a clear negative relation between a bank's GIIPS sovereign debt holdings and its CDS return around the OMT announcement. This relation is also present within the subsample of GIIPS banks, as shown by panel B. See Table A1 for corresponding regression results.

17 The median OMT windfall gain in our sample is $0.9 \%$, whereas the mean is $2.9 \%$. Hence, splitting banks at the mean ensures that high-gain banks experienced a significant gain on their sovereign debt holdings. 
Table 2

Descriptive statistics of banks around OMT

A. Banks' reaction

\begin{tabular}{lccc}
\hline & $\begin{array}{c}(1) \\
\text { OMT windfall gain }\end{array}$ & $\begin{array}{c}(2) \\
\text { GIIPS/assets }\end{array}$ & $\begin{array}{c}(3) \\
\text { CDS return }\end{array}$ \\
\hline Non-GIIPS banks & 0.011 & 0.010 & -0.23 \\
GIIPS banks & 0.08 & 0.118 & -0.96 \\
& & & $(-3.4)$ \\
-test for difference & 5.69 & & 7.8 \\
\hline B. Total assets/total equity ratio & & Crisis/pre-OMT & Post-OMT \\
\hline & Precrisis & 24.3 & 19.6 \\
\hline Weakly capitalized high-gain & 15.3 & 16.1 & 13.9 \\
Well-capitalized high-gain & 15.0 & 17.1 & 16.7 \\
Low-gain & 20.8 & 9.3 & 8.7 \\
U.S. banks & 12.7 & & Post-OMT \\
\hline C. Quasi-leverage ratio & & Crisis/pre-OMT & 40.4 \\
\hline & Precrisis & 71.1 & 17.9 \\
\hline Weakly capitalized high-gain & 22.3 & 26.2 & 28.6 \\
Well-capitalized high-gain & 19.2 & 31.8 & 9.9 \\
Low-gain & 14.4 & 10.1 & \\
U.S. banks & 8.5 & & \\
\hline
\end{tabular}

Panel A presents descriptive statistics about banks' OMT windfall gain, their GIIPS sovereign debt holdings, and their CDS spread reaction to the OMT announcements. Banks included in the analysis are part of the EBA capital exercise prior to the OMT announcement (June 2012) and must be active in the syndicated loan market during the sample period. GIIPS banks include banks incorporated in Italy, Portugal, and Spain. OMT windfall gain is the value gain on banks' sovereign debt holdings as a fraction of total equity. GIIPS/Assets is the banks' GIIPS sovereign debt holdings as a fraction of total assets. Panel B presents the book leverage ratio for different groups of banks, and panel C presents the quasi-leverage, which is defined as market value of equity plus the book value of debt divided by the market value of equity. Precrisis is defined as the average assets/equity ratios for the years 2004-2006. Crisis/pre-OMT is defined as the assets/equity ratio in the year before the OMT announcement, whereas post-OMT is defined as the assets/equity ratio in the year after the OMT announcement. A bank is classified as high-gain (low-gain) bank if its equity capital increase due to the OMT announcement is above (below) the sample mean. A bank is classified as weakly capitalized (well capitalized) if its leverage ratio is less (more) than $2 \%$ above the regulatory threshold post-OMT. $t$-statistics are reported in parentheses.

$2 \%$ of EBA's regulatory capital requirement post-OMT (9\% Tier 1 capital to risk-weighted assets ratio). In the following, we call banks below and above this threshold weakly capitalized and well capitalized, respectively. ${ }^{18}$ Results are robust to using other cutoff points (e.g., $1.5 \%$ or $2.5 \%$ ).

Before the start of the financial and sovereign debt crisis (Column precrisis), both well and weakly capitalized high-gain banks had a lower leverage than low-gain banks (which consist predominantly of non-GIIPS banks). However, while the leverage ratio decreased significantly over time for low-gain banks, it increased dramatically for high-gain banks classified as weakly capitalized (peaking in the year prior to the OMT announcement at 24.3) and increased slightly for well-capitalized high-gain banks over the sovereign debt crisis period (see Column Crisis/pre-OMT).

18 From the banks that experienced high (low) OMT windfall gains, 10 (8) are classified as weakly capitalized and 9 (22) are classified as well capitalized when using the $2 \%$ buffer split. 
Importantly, while the leverage ratio of weakly capitalized high-gain banks improved post-OMT, these banks still remained highly leveraged. Wellcapitalized high-gain banks, on the other hand, were below their precrisis leverage post-OMT (see Column post-OMT). Even more striking is the change of the banks' quasi-leverage ratio, defined as market value of equity plus book value of debt divided by market value of equity (see panel $\mathrm{C}$ of Table 2). Because of the significant decrease of European banks' market-to-book ratio during the crisis (especially for weakly capitalized banks), their quasi-leverage ratio was seven times higher than that of U.S. banks post-OMT. Hence, although the OMT announcement increased the banks' capitalization (and raised most banks above the regulatory minimum of $9 \%$ ), some banks still remained weakly capitalized post-OMT as they still had a very high "risk unweighted" leverage ratio. $^{19}$

\subsection{Bank lending}

To investigate whether and how the OMT announcement affected bank lending, we employ the same methodology as Acharya et al. (2018), that is, a modified Khwaja and Mian (2008) bank lending regression. More precisely, we track the loan volume of different banks (which benefited to a different degree from the OMT announcement) to a certain firm "cluster," thereby controlling for loan demand and any observed and unobserved borrower characteristics shared by firms in the same cluster that might influence loan outcomes.

This approach generates slightly more time-series bank lending heterogeneity than employing firm fixed effects, which allows us to analyze lending on a quarterly basis and thus better identify the effect of the OMT announcement. ${ }^{20}$ This firm clustering approach also has been used by Degryse et al. (2017), who show that it leads to very similar results as the firm fixed effects approach, and, importantly, does not create any bias in the estimation.

We form firm clusters based on three criteria, which capture important drivers of loan demand and firm quality: (1) the country of incorporation; (2) the industry; and (3) the firm rating. ${ }^{21}$ The first two criteria are motivated by the fact that firms in a particular industry and country share many characteristics and were thus affected similarly by macroeconomic developments. Forming clusters based on ratings follows from studies that shows that credit quality affects a firm's loan demand (e.g., Diamond 1991). This clustering generates relatively small and homogenous clusters with on average only 2.8 firms per cluster (the median firm cluster size is 2).

19 This can be explained by the fact that banks met the minimum capital requirement mainly by reducing their risk-weighted assets, instead of increasing their equity capital (see Gropp et al. forthcoming).

20 The quarter-to-quarter change in bank-firm lending relationships tends to be relatively low in DealScan as syndicated loans typically have long maturities and DealScan contains information at the time of the loan origination only.

21 Because only a small fraction of all firms in our sample have a rating from one of the rating agencies, we assign ratings estimated from 3-year median IC ratio by rating category provided by Standard \& Poor's. 


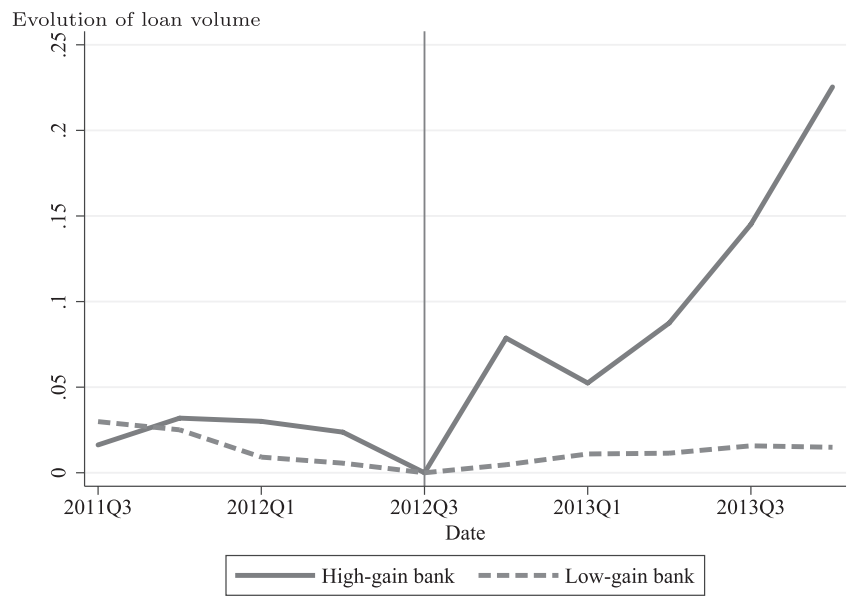

Figure 1

Evolution of loan volume

This figure shows the log-ratio of total loans in a given quarter relative to the quarter of the OMT announcement; that is, the $y$-axis is normalized to 0 at the time of the OMT announcement, controlling for firm-cluster fixed effects. For each quarter, we aggregate all loans to firms borrowing from banks that are covered by the EBA's June 2012 capital exercise. A bank is classified as high-gain (low-gain) bank if its equity capital increase due to the OMT announcement is above (below) the sample mean. The vertical line represents the OMT announcement period in 2012Q3.

3.2.1 Loan volume. Figure 1 plots the $\log$ of the total quantity of loans provided by high- and low-gain banks in a given quarter, respectively. While banks that strongly benefited from the OMT announcement significantly increased their loan supply after 2012Q3, the loan supply provided by low-gain banks remained at roughly the same level.

Next, we formally investigate whether banks with higher OMT windfall gains increased their loan supply to existing borrowers (intensive margin) and/or to firms with which no relation existed pre-OMT (extensive margin) more than banks with a relatively low $O M T$ windfall gain. Our preferred specification to estimate the quarterly loan volume change $\Delta$ Volume $_{b m t+1}$ by bank $b$ to existing borrowers in firm cluster $m$ in quarter $t$ is

$$
\begin{aligned}
y_{b m t+1}= & \beta_{1} \cdot \text { OMT windfall gain }_{b} \cdot \text { PostOMT }_{t}+\gamma \cdot X_{b t} \\
& + \text { Firm Cluster }_{m} \cdot \text { Quarter-Year }_{t+1}+\text { Firm Cluster }_{m} \cdot \text { Bank }_{b} \\
& +u_{b m t+1},
\end{aligned}
$$

where the firm clusters only consist of firms that had a pre-OMT relation with a bank. $\Delta$ Volume is the difference in the log loan volume and is calculated based on asset-weighted shares provided by the lead arrangers. ${ }^{22}$ Our main variable

22 Our results are also robust to employing equal weights. 
of interest is $O M T$ windfall gain interacted with a dummy variable PostOMT, which is equal to one when the quarter is in the post-OMT period.

For the extensive margin, our dependent variable is the indicator

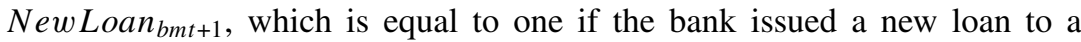
firm cluster to which no relation existed pre-OMT. Our preferred specification for the extensive margin is the same used in Equation (2), where now the firm clusters consist of firms with no prior relation (pre-OMT) with the respective lender.

We present the results of this empirical analysis in Table 3, where, for brevity, we only report the results for our main variable of interest, the $O M T$ windfall gain. The results in panel A show that banks with higher windfall gains from the OMT announcement significantly increased their loan supply to existing borrowers (intensive margin) post-OMT. This result holds across all specifications (Columns 1-3), which control for different sets of fixed effects.

In our least restrictive specification, we control for firm-cluster, time, bank fixed effects, and time varying bank control variables (see Column 1). Column

Table 3

Loan volume regressions

A. Intensive margin: All firms

\begin{tabular}{|c|c|c|c|c|c|c|}
\hline & $\begin{array}{c}(1) \\
\text { All banks } \\
\Delta \text { Loans }\end{array}$ & $\begin{array}{c}\text { (2) } \\
\text { All banks } \\
\Delta \text { Loans }\end{array}$ & $\begin{array}{c}\text { (3) } \\
\text { All banks } \\
\Delta \text { Loans }\end{array}$ & $\begin{array}{c}(4) \\
\text { All banks } \\
\Delta \text { Loans }\end{array}$ & $\begin{array}{l}\text { (5) } \\
\text { All banks } \\
\text { Loan inc. }\end{array}$ & $\begin{array}{c}(6) \\
\text { GIIPS banks } \\
\Delta \text { Loans }\end{array}$ \\
\hline OMT windfall gain*PostOMT & $\begin{array}{l}0.287^{* * *} \\
(4.03)\end{array}$ & $\begin{array}{l}0.241^{* * *} \\
(2.76)\end{array}$ & $\begin{array}{l}0.253^{* *} \\
(2.57)\end{array}$ & & $\begin{array}{l}0.227^{* *} \\
(2.17)\end{array}$ & $\begin{array}{l}0.276^{* *} \\
(2.16)\end{array}$ \\
\hline $\begin{array}{l}R^{2} \\
N\end{array}$ & $\begin{array}{c}.098 \\
15,930\end{array}$ & $\begin{array}{c}.736 \\
15,930\end{array}$ & $\begin{array}{c}.774 \\
15,930\end{array}$ & & $\begin{array}{c}.702 \\
15,930\end{array}$ & $\begin{array}{r}.763 \\
6,518\end{array}$ \\
\hline \multicolumn{7}{|l|}{ B. Extensive margin: All firms } \\
\hline & New loan & New loan & New loan & & & New loan \\
\hline OMT windfall gain*PostOMT & $\begin{array}{l}0.086 \\
(1.12)\end{array}$ & $\begin{array}{c}0.020 \\
(0.65)\end{array}$ & $\begin{array}{l}0.022 \\
(0.74)\end{array}$ & & & $\begin{array}{l}-0.009 \\
(-0.19)\end{array}$ \\
\hline $\begin{array}{l}R^{2} \\
N\end{array}$ & $\begin{array}{c}.048 \\
18,291\end{array}$ & $\begin{array}{c}.594 \\
18,291\end{array}$ & $\begin{array}{c}.627 \\
18,291\end{array}$ & & & $\begin{array}{r}.669 \\
8,655\end{array}$ \\
\hline $\begin{array}{l}\text { Bank-level controls } \\
\text { Firm-cluster fixed effects } \\
\text { Time fixed effects } \\
\text { Bank fixed effects } \\
\text { Firm-cluster-bank fixed effects } \\
\text { Firm-cluster-time fixed effects }\end{array}$ & $\begin{array}{l}\text { Yes } \\
\text { Yes } \\
\text { Yes } \\
\text { Yes } \\
\text { No } \\
\text { No }\end{array}$ & $\begin{array}{l}\text { Yes } \\
\text { No } \\
\text { No } \\
\text { Yes } \\
\text { No } \\
\text { Yes }\end{array}$ & $\begin{array}{l}\text { Yes } \\
\text { No } \\
\text { No } \\
\text { No } \\
\text { Yes } \\
\text { Yes }\end{array}$ & & $\begin{array}{l}\text { Yes } \\
\text { No } \\
\text { No } \\
\text { No } \\
\text { Yes } \\
\text { Yes }\end{array}$ & $\begin{array}{l}\text { Yes } \\
\text { No } \\
\text { No } \\
\text { No } \\
\text { Yes } \\
\text { Yes }\end{array}$ \\
\hline \multicolumn{7}{|l|}{ C. Intensive margin: Quality split } \\
\hline & $\begin{array}{l}\text { All banks } \\
\Delta \text { Loans }\end{array}$ & $\begin{array}{l}\text { All banks } \\
\Delta \text { Loans }\end{array}$ & $\begin{array}{l}\text { All banks } \\
\Delta \text { Loans }\end{array}$ & $\begin{array}{l}\text { All banks } \\
\Delta \text { Loans }\end{array}$ & $\begin{array}{l}\text { All banks } \\
\text { Loan inc. }\end{array}$ & $\begin{array}{c}\text { GIIPS banks } \\
\Delta \text { Loans }\end{array}$ \\
\hline OMT windfall gain*PostOMT & $\begin{array}{c}0.039 \\
(0.56)\end{array}$ & $\begin{array}{l}-0.064 \\
(-1.01)\end{array}$ & $\begin{array}{l}-0.045 \\
(-1.04)\end{array}$ & & & \\
\hline $\begin{array}{l}\text { OMT windfall gain*PostOMT } \\
\text { *Low-IC }\end{array}$ & $\begin{array}{l}0.348^{* *} \\
(2.50)\end{array}$ & $\begin{array}{l}0.286^{* *} \\
(2.07)\end{array}$ & $\begin{array}{l}0.251^{* *} \\
(2.12)\end{array}$ & $\begin{array}{l}0.309^{* *} \\
(2.30)\end{array}$ & $\begin{array}{l}0.319^{* *} \\
(2.25)\end{array}$ & $\begin{array}{l}0.399^{* * *} \\
(3.16)\end{array}$ \\
\hline $\begin{array}{l}R^{2} \\
N\end{array}$ & $\begin{array}{c}.098 \\
15,930\end{array}$ & $\begin{array}{c}.737 \\
15,930\end{array}$ & $\begin{array}{c}.778 \\
15,930\end{array}$ & $\begin{array}{c}.772 \\
15,930\end{array}$ & $\begin{array}{c}.706 \\
15,930\end{array}$ & $\begin{array}{r}.778 \\
6,518\end{array}$ \\
\hline
\end{tabular}


Table 3

Continued

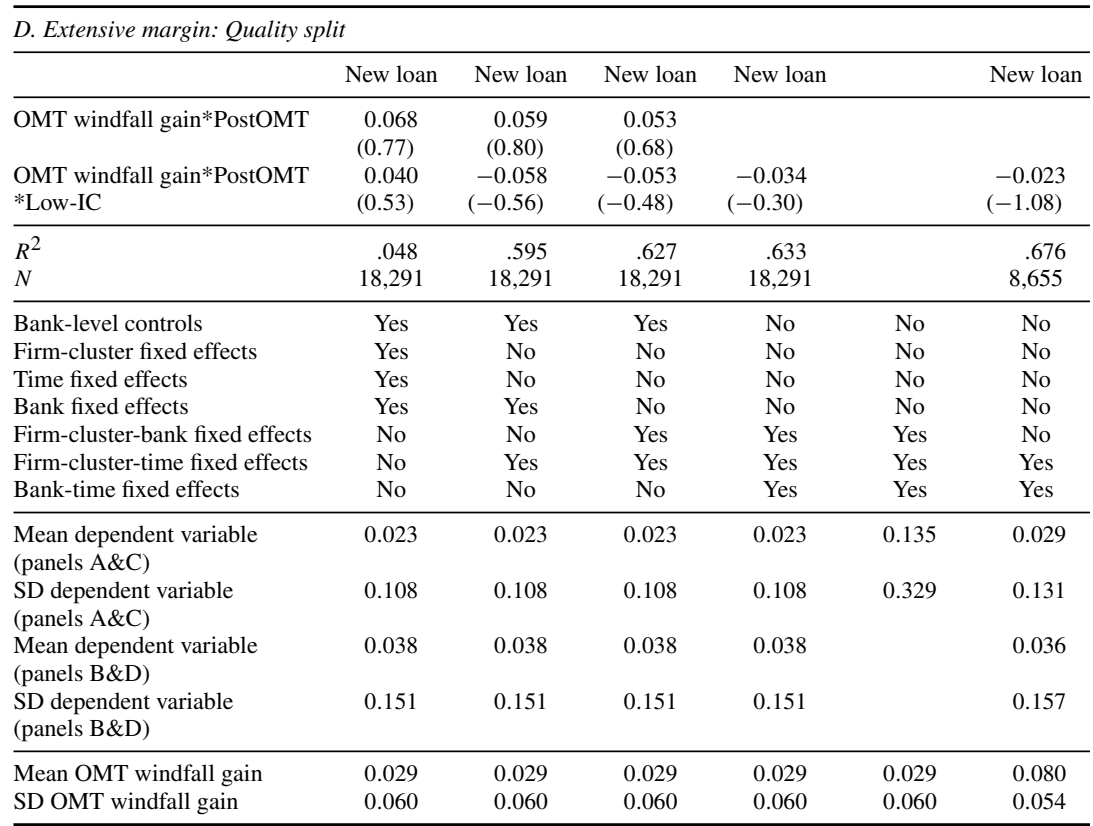

This table presents the results of a modified Khwaja and Mian (2008) bank lending channel regression. The unit of observation is a firm cluster-bank-quarter year. In panels $\mathrm{A}$ and $\mathrm{C}$, the dependent variable is the change in loan volume of a firm cluster-bank relation in a given quarter. In panels B and D, the dependent variable is a dummy equal to 1 if a new loan is issued to a firm cluster with which no prior relation existed. Firm clusters are formed based on a firm's country of incorporation, industry, and rating. OMT windfall gain is the value gain on banks' sovereign debt holdings as a fraction of total equity. PostOMT is an indicator variable equal to 1 starting in quarter four of 2012 and 0 before. A firm is classified as high-IC (low-IC) ratio firm if its 2009-2011 median IC ratio is above (below) the country-specific 2009-2011 median IC ratio. Bank-level controls include the logarithm of total assets, equity/assets, impaired loans/equity, and return on assets. Standard errors are clustered at the bank-level. $t$-statistics are reported in parentheses. $* p<0.10 ; * * p<0.05 ; * * * p<0.01$.

2 shows the regression results for the case in which we also include firm-clustertime fixed effects, which allow us to control for any observed and unobserved time-varying characteristics that are shared by firms in the same cluster. In Column 3, we additionally interact firm-cluster and bank fixed effects, which exploits the variation within the same firm-cluster-bank relationship over time. This controls for any unobserved characteristics common to firms in the same cluster, bank heterogeneity, and for relationships between firms in a given cluster and the respective bank. The coefficient in Column 3 suggests that a 1-standard-deviation higher OMT windfall gain led to a $1.5 \mathrm{pp}$ loan volume increase at the intensive margin.

To further test the robustness of these results, we follow Peek and Rosengreen (2005) and Giannetti and Simonov (2013) and employ the probability of a loan increase instead of the loan amount change as dependent variable. Column 5 of Table 3, panel A, confirms that our results are robust to using this alternative 
lending supply measure. Finally, in Column 6 of Table 3 we restrict our sample to GIIPS banks. Recall that especially GIIPS banks benefited from the OMT announcement because of their large GIIPS sovereign debt exposures. The results show that also within the subsample of GIIPS banks, those banks with higher windfall gains increased lending to existing borrowers more. Finally, in Table A3 we replace the OMT windfall gain with the CDS announcement return for the OMT program for each bank, which measures the extent to which banks benefited from the OMT announcement based on market price reactions. In addition to the OMT's recapitalization effect, the banks' CDS return also captures the OMT's broad positive impact on the GIIPS economies. All results continue to hold with this alternative measure.

Finally, to mitigate concerns that other factors or shocks could have affected the banks' lending behavior, Figure A3 presents placebo tests that show the absence of treatment effects for placebo program dates and for randomly reassigned levels of treatment intensity. In particular, panel A plots the coefficient for the effect of the OMT windfall gains on the loan volume change for each quarter and shows that $O M T$ windfall gains do not have a significantly positive effect on the banks' loan supply pre-OMT. Post-OMT, however, the effect is persistently positive, significant. For the second placebo test we reassign the OMT windfall gains randomly to banks. Panel B shows that in none of the quarters there is a significant relation between the randomly assigned $O M T$ windfall gains and the change in bank lending.

For lending at the extensive margin, panel $\mathrm{B}$ of Table 3 shows that across all specifications there is no significant relation between a bank's OMT windfall gain and its propensity to issue a new loan to firms with which it did not have a prior relation. These results suggest that only existing borrowers benefited from the OMT-induced loan supply increase.

3.2.2 Borrower quality. To determine whether banks that benefited from the OMT announcement targeted their loan supply increase toward a particular type of borrower, we analyze whether they lent more to low- or high-quality borrowers. We identify low-quality (high-quality) borrowers as firms with a below (above) country median 3-year IC ratio in the crisis years 2009 to 2011 and refer to them in the following as low-IC ratio (high-IC ratio) firms.

The general picture that emerges from Table 3, panel $\mathrm{C}$, is that the loan volume increase (at the intensive margin) post-OMT was primarily driven by lending to low-IC ratio borrowers because only the triple interaction term of OMT windfall gain, post-OMT, and low-IC is significantly positive. This result holds even after controlling for bank-time fixed effects, which absorb any time varying bank characteristics that could drive our results (see Column 4). In particular, including bank-time fixed effects addresses the concern that sovereign bond holdings could be endogenous to bank characteristics in a way that could bias the estimated treatment effect. Table 3, panel D, shows that 
even if we split the firms according to their IC ratio there are no significant loan supply effects at the extensive margin.

3.2.3 Contemporaneous shocks. A concern is that bank lending could have been affected by contemporaneous bank-level shocks that were correlated with our OMT windfall gain variable.

The first measure that potentially could have led to interfering effects is the ECB's LTRO, which was allotted in December 2011 (LTRO1) and February 2012 (LTRO2) to provide more liquidity to the European banking system. Its distinctive feature compared to preexisting liquidity facilities was its longer (3-year) maturity, while interest rate and haircut did not differ.

However, while the LTRO program improved the banks' liquidity, we do not see a credit expansion between the LTRO launch and the OMT announcement (see Figure 1). In line with this evidence, Carpinelli and Crosignani (2017) find that, even though the LTRO program helped to limit the lending contraction, the loan supply nevertheless decreased post-LTRO. A likely explanation is that banks had to use the LTRO-induced liquidity to safeguard against massive deposit withdrawals as, in early 2012, the European financial markets were characterized by high uncertainty and even small negative events could have had potentially large consequences. ${ }^{23}$ Following Veronesi and Zingales (2010), the Online Appendix shows that, indeed, the bank run risk was sizable preOMT especially for GIIPS banks, but significantly decreased post-OMT for banks with higher OMT windfall gains. This evidence suggests that the OMT announcement helped the affected banks to free up the liquidity acquired under the LTRO program to grant new loans.

A second contemporaneous shock that potentially affected banks' loan supply is EBA's 2011 capital exercise, which required a subset of European banks to increase their Tier 1/risk-weighted assets ratio to $9 \%$ by the end of June 2012 (i.e., 1-month pre-OMT). One distinct feature of this capital exercise was that it included a surcharge for the banks' sovereign bond holdings, which implies that its effect is likely correlated with our OMT windfall gain variable. However, Gropp et al. (forthcoming) document that the affected banks increased their risk-weighted capital ratio mainly by reducing their risk-weighted asset (as opposed to an equity increase), which led to a credit supply reduction. Our bank lending results are thus conservative as the effect of the capital exercise, if any, acted in the opposite direction of the OMT announcement and thus biases our results downward.

Finally, our results could have been influenced by two EU policy responses to the eurozone crisis, the European Stability Mechanism (ESM) and the European

23 Between $20 \%$ to $50 \%$ of bank deposits are held overnight and thus can be withdrawn at short notice. For example, British customers withdrew 200 million pounds the day after the rating downgrade of Banco Santander in May 2012, and some analysts estimated that banks would have lost up to $10 \%$ of their deposit base if Greece had left the eurozone in 2012. See Enrich, Schaefer Munoz, and Charles Forelle (2012). 
Financial Stability Facility (EFSF). ${ }^{24}$ In particular, in December 2012, the ESM approved a support package for the recapitalization of Spanish banks (the main recipients were Banco de Valencia, Bankia, Catalunya Banc, and NCG Banco). However, none of the recipient banks was part of the EBA's capital exercise from June 2012 and thus included in our sample, which rules out that this measure affects our results. Moreover, in May 2011, a financial assistance package for Portugal was approved under the umbrella of the EFSF. Using 3.8bn Euro from this bailout package, Millennium bcp was rescued in June 2012. While this bank was part of EBA's capital exercise and thus is part of our sample, all our results hold when we exclude Millennium bcp from our analysis.

\section{Zombie Lending}

Weak firms with preexisting lending relationships benefiting from the increased loan supply is consistent with both, the firm balance-sheet channel (Bernanke and Gertler 1995) and zombie lending (Caballero, Hoshi, and Kashyap 2008). According to the firm balance-sheet channel, the OMT-induced positive macro shock increased the credit quality of the banks' borrower pool by improving the outlook of their investment opportunities, net worth, and collateral. In turn, extending new loans to these borrowers at appropriately priced loan rates was again a positive net present value (NPV) investment.

In contrast, according to the zombie lending channel, banks that remained weakly capitalized post-OMT had an incentive to extend subsidized (negative NPV) loans at advantageous interest rates to existing distressed borrowers to avoid (or at least defer) having to declare outstanding loans nonperforming. This reclassification would have lowered the banks' net operating income, required them to raise provisioning levels, and also would have tied up even more equity capital due to higher risk weights on impaired assets (see Aiyar et al. 2015 and Jassaud and Kang 2015). In turn, regulatory scrutiny and pressure from market forces would have been more intense, which would have further deteriorated the banks' situation.

In the following, we use these distinguishing features to determine which channel triggered the banks' lending increase to low-quality borrowers. First, we check whether these loans had subsidized interest rates post-OMT, which would be a strong indication for zombie lending. Second, we track the borrowers' financial and real outcomes pre- and post-OMT. If the firms' weak performance pre-OMT was due to fundamental economic problems, their performance should have remained poor even after banks increased their loan supply (evidence for zombie lending). If, however, the poor performance was caused by financial constraints, these firms should have recovered after they

24 Recall that we are not able to calculate the $O M T$ windfall gain for Greek and Irish banks because their sovereign debt is mostly domestic, and Greek and Irish sovereign yields are mostly missing (see also Krishnamurthy et al. 2018). 
regained access to bank financing post-OMT (evidence for the firm balance sheet channel).

Accordingly, we first investigate whether and how banks adjusted their interest rates post-OMT. Table A4 shows that weakly capitalized banks with high $O M T$ windfall gains significantly reduced the interest rates for low-quality firms, while leaving the rates for high-quality firms unchanged. In contrast, wellcapitalized banks slightly reduced the interest rate charged to high-quality firms and did not significantly change their lending rates to low-quality firms. This lending pattern is a first indication for zombie lending by weakly capitalized banks.

To detect subsidized zombie lending, we follow Caballero, Hoshi, and Kashyap (2008) and Giannetti and Simonov (2013) and check whether distressed firms obtained loans at below-market interest rates. More precisely, a firm is considered to have received subsidized credit (i.e., loans at advantageous interest rates) if in a given year the firm's interest expense is below the expense paid by the most creditworthy firms in the economy. As benchmark firms, we use AAA-rated (inferred from ICs) public firms incorporated in non-GIIPS countries. $^{25}$ These firms were least affected by the sovereign debt crisis, because they were less exposed to the downturn in the European periphery and were able to substitute a potential lack of bank financing with other funding sources (Acharya et al. 2018).

For our main zombie definition, we calculate the interest rate benchmark based on information from Amadeus (index $A$ ). ${ }^{26}$ In what follows we use $r$ for interest rates and $R$ for interest expenses. Amadeus reports the total interest payments of firm $i$ in country $j$ and industry $h$ in year $t, R_{i j h t}$, as well as its total outstanding debt, $D e b t_{i j h t}$. The average interest rate paid by firm $i$ thus can be calculated by dividing $R_{i j h t}$ by $D e b t_{i j h t}$. While we are not able to distinguish between the interest paid on different maturities in the Amadeus data, it provides information about the firms' reliance on short- and long-term debt which we use to divide firms into two groups. The benchmark rates for firms that rely mostly on short- and long-term debt, respectively, are derived from AAA-rated public firms with a similar debt maturity structure. That is, the interest rate benchmark for a given firm, $r_{g t}^{A}$ (with $g \in\{s, l\}$ where $s$ is shortterm and $l$ is long-term), is calculated using the median interest rate paid by all public AAA-rated firms incorporated in non-GIIPS countries in a given year, split according to their reliance on short versus long-term debt.

Given this benchmark, we calculate the threshold $R_{i j h t}^{A^{*}}$ below which the interest payment of firm $i$ in country $j$ and industry $h$ in year $t$ is considered

25 Significant differences exist in the pricing of syndicated loans between U.S. and European loans (U.S. firms pay significantly higher spreads; see Berg et al. 2016), so we have to rely on creditworthy European firms and cannot use U.S. firms to calculate the benchmark interest rate.

26 Alternatively, we use loan information from DealScan to calculate the benchmark rate (denoted with index $D$ ). Doing so yields very similar results. See the Online Appendix for a detailed explanation. 
subsidized as

$$
R_{i j h t}^{A^{*}}=r_{g t}^{A} \cdot D e b t_{i j h t} .
$$

Figure 2, panel A, plots the evolution of the benchmark interest rates over time, as well as, the median interest payment of zombie firms.

We then compare the actual interest payments of the borrowers in our sample with the hypothetical interest payments to calculate the interest expense gap:

$$
x_{i j h t}^{A^{*}}=R_{i j h t}-R_{i j h t}^{A^{*}} .
$$

Finally, a firm $i$ is classified as zombie if it meets the following three criteria: (a) its $x_{i j h t}^{A *}$ is negative, (b) its rating (derived from 3-year median ICs) is BB or lower, and (c) the syndicate composition has either remained constant, or banks that left the syndicate were not replaced by new participants, that is, the same syndicate has already provided a loan to the firm. ${ }^{27}$ By imposing the second criterion on zombies, we reduce the risk of misclassifying high-quality borrowers as zombies because these firms may pay low interest rates on their debt for reasons unrelated to zombie lending. By requiring zombies to fulfill the last criterion, we ensure that all involved banks have zombie lending incentives, that is, all banks have a stake in the company from a prior loan.

To ensure the robustness of our results with respect to the zombie classification, we employ various alternative zombie definitions in the Online Appendix. First, instead of a crisp zombie definition, we employ fuzzy zombie measures where a firm can be a zombie "to a certain degree." Second, we do not require a firm to be of low-quality to be classified as zombie. Third, we replace the unique interest rate benchmark across all industries with an industry-specific benchmark interest rate. All results remain similar when using these alternative zombie classifications.

\subsection{Evolution and characteristics of zombie firms}

Table 4, panel A, presents a breakdown of the number of zombie firms by country. The table documents that the zombie problem is particularly severe in the periphery of Europe, with Spain and Italy having around 18\% to $20 \%$ of zombie firms, while Germany, France, and the UK only have between $7 \%$ and $12 \%$ zombie firms. $^{28}$

Figure 2, panel B, plots the fraction of zombie firms in our sample over time. The figure shows that the asset-weighted fraction of zombie firms significantly increased in the post-OMT period. This "rise of the zombies" can be explained by several mutually reinforcing factors. The number of impaired borrowers

27 Given that (a) and (b) are satisfied, (c) holds in $95 \%$ of the cases.

28 The zombie prevalence by country in our sample is also in line with anecdotal evidence from the financial press, which stated that "the zombie problem is chiefly focused in the peripheries of Europe rather than the core." See Stothard (2013). 

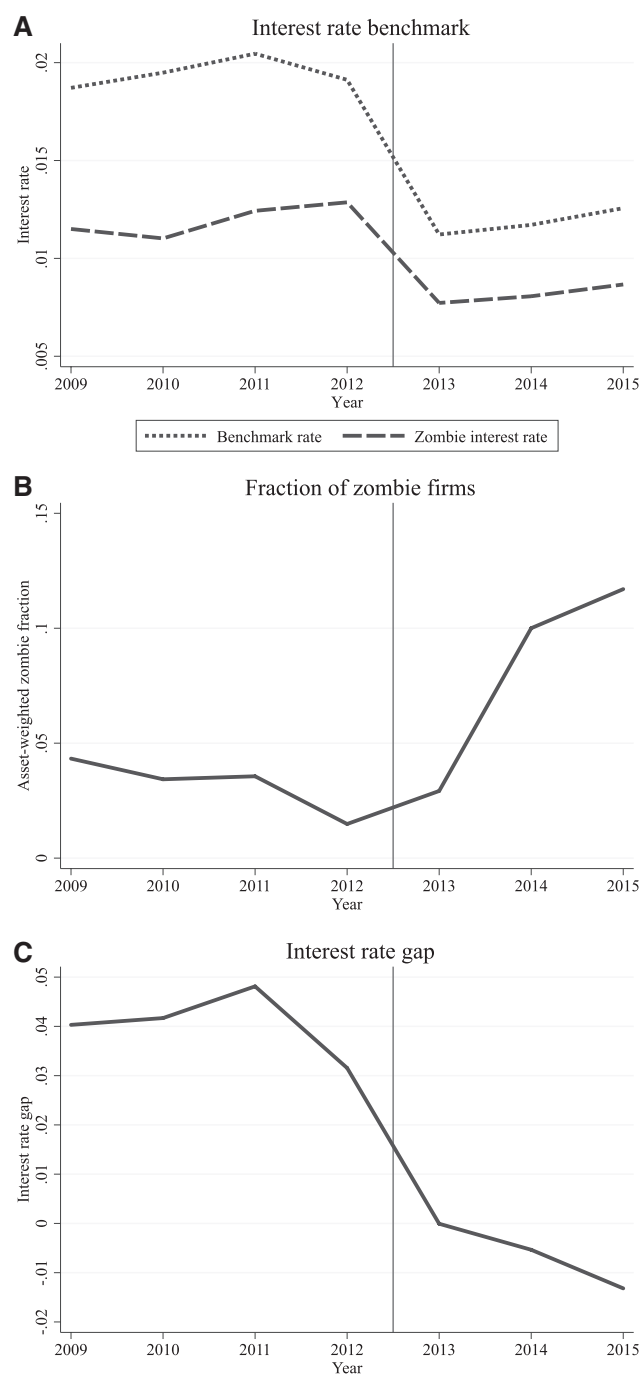

Figure 2

Benchmark interest rates and fraction of zombie firms

Panel A shows the average benchmark interest rate (blue-dotted line) and the median interest rate paid by zombie firms (red-dashed line). Panel B shows the asset-weighted fraction of zombie firms in our sample. Panel C shows the average interest rate gap for firms that only became a zombie post-OMT. We classify a firm as zombie if it meets the following three criteria: (1) the firm received subsidized credit, (2) its rating (derived from 3-year median ICs) is BB or lower, and (3) the syndicate composition has either remained constant, or banks that left the syndicate were not replaced by new participants; that is, the same syndicate has already provided a loan to the firm. The vertical line represents the OMT announcement period in 2012Q3.

strongly increased during the crisis, which increased the pool of borrowers needing subsidized credit to stay afloat. While weakly capitalized banks likely already had zombie lending incentives pre-LTRO/OMT, they were not able 
Table 4

Descriptive statistics

A. Breakdown of zombie firms by country

\begin{tabular}{|c|c|c|c|c|}
\hline Country & $\begin{array}{l}\text { Zombie firms/ } \\
\text { Total borrowers }\end{array}$ & $\begin{array}{l}\text { \# of firms } \\
\text { in sample }\end{array}$ & & \\
\hline Germany & $11(7 \%)$ & 167 & & \\
\hline Spain & $37(18 \%)$ & 201 & & \\
\hline France & $20(10 \%)$ & 203 & & \\
\hline United Kingdom & $33(12 \%)$ & 286 & & \\
\hline Italy & $40(20 \%)$ & 198 & & \\
\hline \multicolumn{5}{|l|}{ B. Difference in group of firms } \\
\hline & High-IC ratio & Low-IC ratio no zombie & Zombie & Difference (2)-(3) \\
\hline Total assets (mn) & 3,130 & 2,820 & 2,110 & $\begin{array}{l}710^{* *} \\
(2.05)\end{array}$ \\
\hline Tangibility & 0.556 & 0.598 & 0.491 & $\begin{array}{l}0.107^{* * * *} \\
(6.68)\end{array}$ \\
\hline Int. cov. & 6.645 & 1.790 & 0.230 & $\begin{array}{l}1.56^{* * *} \\
(8.28)\end{array}$ \\
\hline Net worth & 0.309 & 0.223 & 0.186 & $\begin{array}{l}0.037^{* * *} \\
(2.91)\end{array}$ \\
\hline EBITDA/Assets & 0.134 & 0.077 & 0.030 & $\begin{array}{l}0.047^{* * *} \\
(11.92)\end{array}$ \\
\hline Leverage & 0.602 & 0.709 & 0.742 & $\begin{array}{l}-0.033^{* * *} \\
(-2.84)\end{array}$ \\
\hline Loan amount/Total assets (\%) & 21.25 & 18.80 & 21.92 & $\begin{array}{l}-3.12 \\
(-1.48)\end{array}$ \\
\hline Maturity (months) & 60.03 & 63.35 & 61.39 & $\begin{array}{c}1.96 \\
(0.58)\end{array}$ \\
\hline Term loan $(\%)$ & 53.31 & 51.76 & 54.38 & $\begin{array}{c}-2.62 \\
(-0.58)\end{array}$ \\
\hline
\end{tabular}

Panel A presents a breakdown of the number of zombie firms by country where the fraction of all sample firms in a given country is shown in parentheses. Panel B presents a test for the difference in means between low-IC nonzombie firms and zombie firms. A firm is classified as high-IC (low-IC) ratio firm if its 2009-2011 median IC ratio is above (below) the country-specific 2009-2011 median IC ratio. For the definition of a zombie firm see the caption of Figure 2. $* p<0.10 ; * * p<0.05 ; * * * p<0.01$.

to act on these incentives on a large scale due to bank run risk and lack of liquidity and capital (see Section A1 in the Online Appendix). Post-LTRO, weakly capitalized banks had sufficient liquidity but no capital to lend. PostOMT, banks then had both, sufficient liquidity and capital, to significantly increase lending (see Figure 1). However, a significant fraction of banks had still zombie lending incentives post-OMT as they remained weakly capitalized (Table 2, panels B and C), but now they had the lending capacity to fully act on these incentives.

A potential concern is that this growth in the number of zombies was driven by the economic downturn in GIIPS countries and a subsequent deterioration in firm quality as opposed to an increase in zombie lending at subsidized interest rates. More precisely, our results could be driven by the possibility that many firms already received subsidized credit pre-OMT, thereby satisfying zombie criterion (a), but are classified as zombies only after their IC deteriorated enough during the economic downturn to also satisfy the low-quality zombie criterion (b). In this case the increase in the number of zombies would not have been caused by an active decision of the banks. 
To mitigate this concern, we again plot the evolution of the asset-weighted fraction of zombies in Figure B1, but without requiring firms to be of low-quality to be classified as zombie (i.e., we drop criterion b). We denote this zombie definition Zombie3. ${ }^{29}$ The figure shows that the zombie prevalence follows the same trend when using this alternative zombie definition as compared to using our main definition. This evidence indicates that the increase in the zombie prevalence was indeed driven by more firms getting subsidized credit and not a deterioration in firm quality.

Figure 2, panel C, shows that firms that only became zombies post-OMT (i.e., firms that contributed to the zombie increase) paid pre-OMT interest rates which have been between 1-5 pp above the rates paid by the benchmark firms. Hence, these firms only satisfied the subsidized lending zombie criterion post-OMT. This evidence shows, first, that these firms did not always receive subsidized loans, mitigating concerns that some time-invariant firm fundamentals allow them to pay low interest rates on their debt in general. Second, it indicates that the drop in interest rates played an important role for the zombie prevalence increase.

Table 4, panel B, which compares the characteristics of zombie to nonzombie firms, shows that, on average, zombie firms have a significantly higher leverage, and lower net worth and profitability (EBITDA/Assets) ratios. ${ }^{30}$ Most importantly, zombie firms only have an IC ratio of 0.23 as opposed to 1.79 for other low-IC ratio firms. Hence, these firms were unable to meet their current interest payments from the earnings generated. To avoid default events, banks thus had to either provide them with additional cheap liquidity through new subsidized loans and/or lower the interest rates of their preexisting loans to below market-rate levels (which led to a spike in loan amendments post-OMT, as shown in the Online Appendix).

Finally, a potential concern could be that other loan characteristics of zombie firms, besides the cost of borrowing, are significantly different. Even though we derive the benchmark interest rates separately for short- and long-term loans, it could still be that within these two maturity brackets, loans to zombie firms are, for example, of significantly shorter maturity. This could justify a reduction in their borrowing costs. However, when comparing the loan characteristics of zombie and other nonzombie firms with low-IC ratios we do not find any significant differences (see Table 4, panel B). More precisely, these loans are of similar size and have a similar maturity. Moreover, there is also no significant difference in the loan type (term loan vs. revolver) extended to these firms that could lead to loan pricing differences. ${ }^{31}$ Hence, the lower

29 Table B1 provides an overview over all alternative zombie definitions.

30 These results show that even within the group of low-IC ratio firms, zombie firms are of significantly worse quality compared to nonzombie firms on observable solvency and liquidity ratios.

31 We cannot observe covenants for our loan contracts, because this information is missing for most loans in DealScan. 
borrowing costs for zombie firms do not seem to be due to differences in loan characteristics.

\subsection{Lending to zombie firms}

Figure 3, panel A, shows that banks that regained some lending capacity due to their windfall gains from the OMT announcement (high-gain banks), but which still remained weakly capitalized, show a strong increase in their zombie loan volume relative to their total assets post-OMT. Panel B shows that this significant increase is mainly driven by weakly capitalized banks located in GIIPS countries. Conversely, well-capitalized high-gain banks significantly reduced their zombie lending as fraction of total asset post-OMT.

To formally test for the difference in post-OMT zombie lending behavior as a function of bank capitalization, we estimate the quarterly change in loan volume provided by bank $b$ to firm cluster $m$ in quarter $t$ by employing the following panel regression:

$$
\begin{aligned}
& \Delta \text { Volume }_{b m t+1}= \\
& \beta_{1} \cdot \text { OMT windfall gain } \text { w }_{b} \cdot \text { PostOMT }_{t}
\end{aligned}
$$

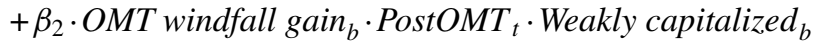

$$
\begin{aligned}
& +\beta_{3} \cdot \text { OMT windfall } \text { gain }_{b} \cdot \text { PostOMT }_{t} \cdot \text { Zombie }_{m t}
\end{aligned}
$$

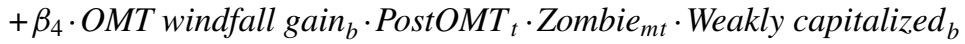

$$
\begin{aligned}
& +\gamma \cdot X_{b t}+\text { Firm Cluster }_{m} \cdot \text { Quarter-Year } \text { Yut }_{t+1} \\
& + \text { Firm Cluster }_{m} \cdot \text { Bank }_{b}+u_{b m t+1} \text {. }
\end{aligned}
$$

Note that we also control for all other pairwise and triple interaction terms if they are not absorbed by the fixed effects, but omit them in Equation (5) for brevity. Moreover, in addition to the criteria used to form firm clusters in Section 3.2, we add the criterion whether firms are classified as zombie for this analysis. This extra criterion leads to a larger number of firm clusters than in our loan volume analysis. That is, the firm clusters consisting of zombies have on average only 1.3 firms per cluster with a median of 1. Finally, note that, for our regression analysis, we lag the Zombie indicator by one period like in Giannetti and Simonov (2013), because the nonlagged zombie dummy itself would constitute an outcome of a bank's willingness to extend credit.

Importantly, two factors generate sufficient cross-sectional heterogeneity in the banks' OMT windfall gains and their post-OMT capitalization that allow us to gauge the effects of these two bank characteristics. First, there is no significant relation between banks' precrisis capitalization and GIIPS sovereign debt holdings (Spearman's rank correlation coefficient is only 0.21 and insignificant). Second, the rank correlation between the banks' precrisis GIIPS sovereign debt holdings and their equity change between precrisis and 

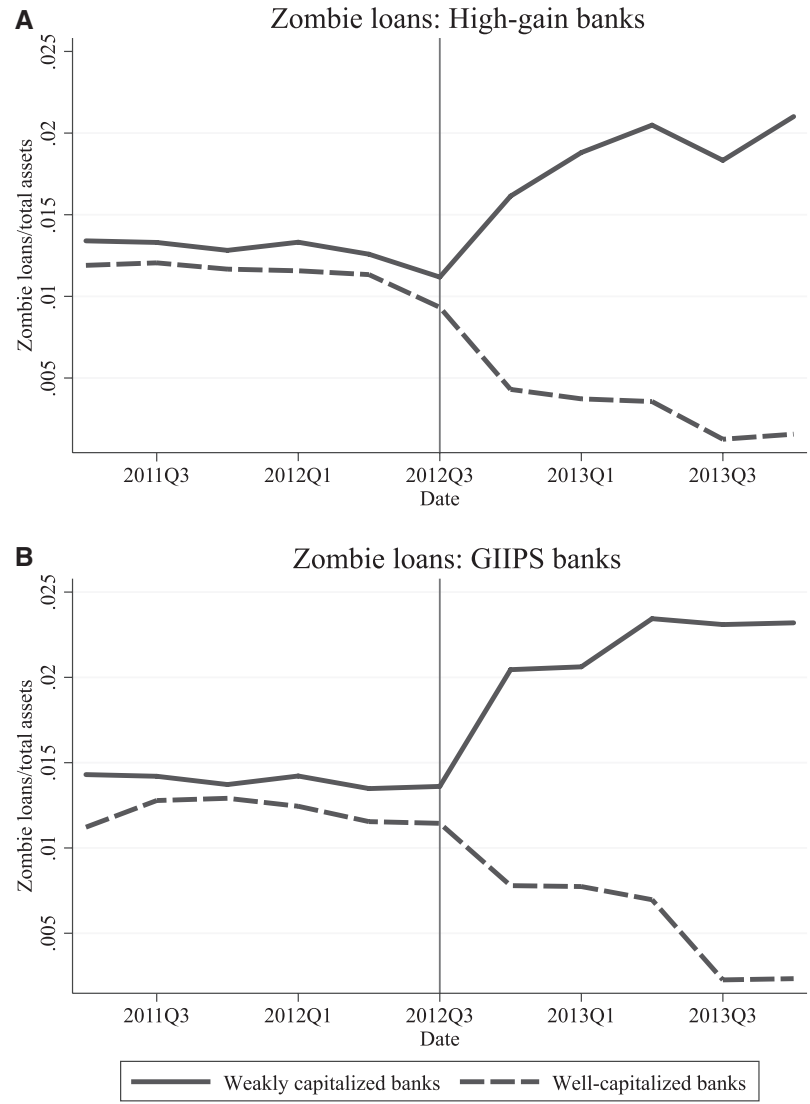

Figure 3

Fraction of zombie loans: High-gain and GIIPS banks

The figure presents the ratio of zombie loans to total assets separately for the subsample of high-gain banks (panel A) and GIIPS banks (panel B). A bank is classified as high-gain (low-gain) bank if its equity capital increase due to the OMT announcement is above (below) the sample mean. A bank is classified as weakly capitalized (well capitalized) if its leverage ratio is less (more) than $2 \%$ above the regulatory threshold post-OMT. See the caption of Figure 2 for the definition of a zombie firm. The vertical line represents the OMT announcement period in 2012 Q3.

post-OMT is -0.49 , which implies that their equity change is also driven by other factors (differences in credit exposure, etc.).

Table 5 presents the results. ${ }^{32}$ Several findings are noteworthy. First, even before the OMT announcement, weakly capitalized banks already engaged in significantly more zombie lending than well-capitalized banks (see Weakly capitalized*Zombie).

32 Table 5 clusters standard errors at the bank level. Tables A5 and A6 show that our results are robust to clustering standard errors at the firm-cluster level and to double clustering them at the bank and firm-cluster levels, respectively. 
Table 5

Loan volume regressions - zombie lending

(3)

(4)

All banks $\Delta$ Loans

OMT windfall gain*PostOMT $\left(\widehat{\beta}_{1}\right)$

Zombie*PostOMT

OMT windfall gain*Zombie

Weakly capitalized*PostOMT $\left(\widehat{\beta}_{5}\right)$

Weakly capitalized*Zombie

Weakly capitalized*PostOMT
*Zombie $\left(\widehat{\beta}_{6}\right)$
OMT windfall gain*PostOMT
*Zombie $\left(\widehat{\beta}_{3}\right)$
OMT windfall gain*PostOMT
*Weaklycapitalized $\left(\widehat{\beta}_{2}\right)$
OMT windfall gain*Weakly
capitalized*Zombie

capitalized*Zombie

OMT windfall gain*PostOMT

*Weaklycapitalized*Zombie $\left(\widehat{\beta}_{4}\right)$

$R^{2}$
$N$

\begin{tabular}{|c|c|c|c|c|c|c|}
\hline$\widehat{\widehat{\beta}_{1}}+\widehat{\beta}_{3}$ & $\begin{array}{c}-0.078 \\
(-0.98)\end{array}$ & $\begin{array}{c}-0.091 \\
(-1.14)\end{array}$ & $\begin{array}{l}-0.064 \\
(-0.85)\end{array}$ & & & \\
\hline$\widehat{\beta}_{1}+\widehat{\beta}_{2}$ & -0.010 & -0.025 & -0.001 & & & \\
\hline & $(-0.16)$ & $(-0.25)$ & $(-0.01)$ & & & \\
\hline$\widehat{\beta}_{2}+\widehat{\beta}_{4}$ & $0.298^{* *}$ & $0.288^{* *}$ & $0.261^{*}$ & & & \\
\hline & (1.97) & $(2.08)$ & $(1.76)$ & & & \\
\hline$\widehat{\beta}_{1}+\widehat{\beta}_{2}+\widehat{\beta}_{3}+\widehat{\beta}_{4}$ & $0.220^{* *}$ & $0.197^{* *}$ & $0.197^{*}$ & & & \\
\hline & $(2.17)$ & $(2.29)$ & $(1.79)$ & & & \\
\hline$\widehat{\beta}_{5}+\widehat{\beta}_{6}$ & 0.001 & -0.001 & -0.002 & & & \\
\hline & $(0.02)$ & $(-0.06)$ & $(-0.09)$ & & & \\
\hline Mean dependent variable & 0.026 & 0.026 & 0.026 & 0.026 & 0.146 & 0.031 \\
\hline SD dependent variable & 0.121 & 0.121 & 0.121 & 0.121 & 0.343 & 0.152 \\
\hline Mean OMT windfall gain & 0.029 & 0.029 & 0.029 & 0.029 & 0.029 & 0.080 \\
\hline SD OMT windfall gain & 0.060 & 0.060 & 0.060 & 0.060 & 0.060 & 0.054 \\
\hline Bank-level controls & Yes & Yes & Yes & No & No & No \\
\hline Time fixed effects & Yes & No & No & No & No & No \\
\hline Firm-cluster fixed effects & Yes & No & No & No & No & No \\
\hline Bank fixed effects & Yes & Yes & No & No & No & No \\
\hline Bank-time fixed effects & No & No & No & Yes & Yes & Yes \\
\hline Firm-cluster-bank fixed effects & No & No & Yes & Yes & Yes & No \\
\hline Firm-cluster-time fixed effects & No & Yes & Yes & Yes & Yes & Yes \\
\hline
\end{tabular}

This table presents the results of a modified Khwaja and Mian (2008) bank lending channel regression used in Table 3. Firm clusters are formed based on a firm's country of incorporation, industry, rating, and whether the firm is a zombie. Hence, clusters consist entirely of zombie or nonzombie firms. OMT windfall gain is the value gain on banks' sovereign debt holdings as a fraction of total equity. Weakly capitalized is a dummy variable that equals one if a bank is less than $2 \%$ above the regulatory capital requirement post-OMT. PostOMT is an indicator variable equal to 1 starting in quarter four of 2012 and 0 before. See the caption of Figure 2 for the definition of a zombie firm. Bank-level controls include the logarithm of total assets, equity/assets, impaired loans/equity, and return on assets. Standard errors are clustered at the bank level. $t$-statistics are reported in parentheses. * $p<0.10$;** $p<0.05 ; * * * p<0.01$. 
Second, conditional on a bank's OMT windfall gains, there is a significant difference in the lending behavior of well versus weakly capitalized banks postOMT. Banks that remained weakly capitalized show no significant increase in their loan supply to nonzombie firms (see $\beta_{1}+\beta_{2}$ ) and lent significantly less to nonzombie firms compared to well-capitalized banks (see $\beta_{2}$ ). However, compared to well-capitalized banks, these banks lent significantly more to zombie firms (see $\beta_{4}$ ). Based on the coefficients reported in Table 5, Column 3, a 1-standard-deviation higher OMT windfall gain for weakly capitalized banks implies a $1.2 \mathrm{pp}$ loan volume increase to zombies.

Banks with high OMT windfall gain that were well capitalized post-OMT, on the other hand, increased the loan supply to nonzombie borrowers postOMT (see $\beta_{1}$ ). In particular, based on the specification in Column 3, a 1standard-deviation higher OMT windfall gain implies a loan supply increase to nonzombie firms by $2.6 \mathrm{pp}$. Moreover, in contrast to weakly capitalized banks, well-capitalized banks reduced their zombie lending activity as a fraction of total lending.

To analyze the zombie lending activity of well-capitalized banks in more detail, we plot the coefficient of $\beta_{1}+\beta_{3}$ (i.e., their lending to zombies postOMT) for each quarter in panel A of Figure A4. This figure shows that, while well-capitalized banks did not cut back on zombie firms immediately, their loan volume reduction to zombies becomes statistically significant after 2013Q2. This pattern can be explained by the fact that banks cannot terminate their outstanding (zombie) loans immediately. Instead, to reduce their zombie exposure, they have to stop rolling over the respective loans once they mature, which results in a delay in their zombie exposure decrease. In line with this explanation, panel B of Figure A4 shows that a significant share of the zombie loans that were issued pre-OMT matured in 2013Q2, which coincides with the time when the sum of the two coefficients (i.e., $\beta_{1}+\beta_{3}$ ) becomes negatively significant.

Third, conditional on the banks' post-OMT capitalization, they behaved differently depending on the magnitude of their OMT windfall gains. Weakly capitalized banks with high $O M T$ windfall gains extended significantly more credit to zombie firms (see $\widehat{\beta}_{1}+\widehat{\beta}_{2}+\widehat{\beta}_{3}+\widehat{\beta}_{4}$ in Table 5). In contrast, weakly capitalized banks with only low OMT windfall gains did not significantly change their lending to nonzombie and zombie firms after the OMT announcement (see Weakly capitalized*PostOMT and Weakly capitalized ${ }^{*}$ PostOMT*Zombie). This evidence supports the notion that the OMT windfall gains facilitated zombie lending by enhancing the weakly capitalized banks' lending capacity.

While the firm-cluster-time fixed effects absorb unobserved shocks to credit demand, our zombie lending results could still be biased by endogeneity of the banks' treatment levels as the exposure to the OMT shock is likely correlated with bank characteristics, such as country of incorporation, capitalization, and appetite for risk. We address this concern by employing two additional tests. 
First, we introduce additional interaction terms in Table A7 between PostOMT, Weakly capitalized, Zombie, and other bank characteristics that could be correlated with the banks' $O M T$ windfall gains. ${ }^{33}$ In particular, we add (1) a dummy for whether a bank has government ownership (High Gov Own; Columns 7-8); (2) a dummy for whether the bank has an above median size (Large Bank; Columns 9-10); (3) a proxy for the banks' business model, that is, commercial bank versus investment bank focused (Loans/Assets; Columns 11-12); and (iv) the fraction of cash from central banks over total assets (Cash/Assets; Columns 13-14), which is a proxy for the banks' funding model and the extent to which they borrowed from central banks over the crisis period. We then run horse races between the interactions with our main variable of interest (OMT windfall gain) and the interactions with these various bank characteristics. Across all horse races the quadruple interaction term on $O M T$ windfall gain*PostOMT*Weakly capitalized ${ }^{*}$ Zombie remains significant.

Second, we add a more restrictive fixed effects setting with bank-time fixed effects to absorb any time varying bank characteristics that could drive our results (see Table 5, Column 4). Our key result that well-capitalized banks significantly reduced their zombie credit exposure as a fraction of their total lending post-OMT, whereas still weakly capitalized banks significantly increased their loan volume to zombie firms, continues to hold. We find similar results when we replace the change in loan volume with a dummy for whether the loan amount to a cluster actually increased (Table 5, Column 5) or when we restrict the analysis to GIIPS banks (Table 5, Column 6). ${ }^{34}$

Moreover, our results show that the treatment effects are similar across banks in different countries. This evidence supports the interpretation that the zombie incentive distortion is independent of local regulation and/or industry structure and is thus not driven by endogenously higher treatment exposure of GIIPS banks, which operate in an environment where baseline exposure to zombie firms and incentives for evergreening are endogenously higher.

Finally, similar to the placebo test presented for the results in Section 3.2.1, we again conduct tests with placebo program dates and randomly reassigned levels of treatment intensity. Figure A3, panel C, plots the coefficient for the zombie lending of weakly capitalized banks interacted with OMT windfall gains over time and shows that there is only a significantly positive effect on bank lending post-OMT. Panel D shows that there is no significant effect on bank lending when we randomly assign the OMT windfall gains.

33 Table A7 clusters standard errors at the bank level. Tables A8 and A9 show that our results are robust to clustering standard errors at the firm-cluster level and to double clustering them at the bank and firm-cluster levels, respectively.

34 Table A10, panel C, shows the robustness of these results for the case in which we use the CDS announcement return for the OMT program for each bank instead of OMT windfall gain. 


\subsection{Alternative explanations for subsidized lending}

The observed subsidized lending of weakly capitalized banks also could be driven by (1) government moral suasion and (2) a credit expansion to GIIPS borrowers by GIIPS banks.

At the peak of the crisis, GIIPS governments might have pressured domestic banks to redirect credit to weak firms at advantageous interest rates to avoid firm defaults and higher unemployment rates. Moreover, if the governments' ability to exert pressure was greater for weakly capitalized banks, then moral suasion could potentially drive our results as only these banks engaged in zombie lending, whereas well-capitalized banks significantly reduced their zombie exposure. ${ }^{35}$

Furthermore, our results could be driven by the possibility that weakly capitalized GIIPS banks cleared a credit backlog post-OMT and lent more to low-quality GIIPS firms at very low interest rates to rapidly expand their credit supply.

We employ four different tests to address these concerns. First, if GIIPS governments indeed exerted pressure, subsidized lending should have been more prevalent for government-owned banks. To investigate this hypothesis, we collect data on the government ownership of all banks in our sample from Bureau van Dijk's Orbis database and conduct a horse race between weakly capitalized and government-owned banks. Columns 1-2 of Table A7 provide the results. Across both specifications, we find that only banks that remained weakly capitalized post-OMT engaged in zombie lending, whereas government-owned banks do not seem to have engaged in zombie lending.

Second, if government moral suasion was widespread, especially government-owned firms should have received subsidized loans. To investigate this possibility, we use ownership information from Amadeus and rerun our lending regressions excluding firms with positive government ownership. ${ }^{36}$ Table A11, panel A, shows that the results remain qualitatively unchanged.

Finally, if weakly capitalized GIIPS banks strongly increased their loan supply to low-quality GIIPS borrowers at advantageous interest rates due to either government moral suasion or a clearance of a credit supply backlog, we would expect a credit increase especially of domestic banks to domestic low-IC ratio firms. To test these hypotheses, we first rerun our main regression but limit the analysis to the (small) subsample of non-GIIPS firms that received funding from GIIPS banks. ${ }^{37}$ Table A7, Columns 3 and 4, show that we obtain similar

35 A potential link between the banks' capitalization and their proneness to moral suasion is that weak banks will more likely need a bailout than will well-capitalized banks and are hence more dependent on the government's goodwill.

36 We thank Vadym Volosovych for providing us with the ownership data. See Kalemli-Ozcan et al. (2015) for details on the construction of these data.

37 Acharya et al. (2018) document that these bank relationships primarily emerged through precrisis bank merger and acquisition (M\&A) transactions, for example, a German bank is taken over by an Italian bank and the German firm borrowing from the German bank before the M\&A transaction is now borrowing from the Italian bank. 
results when focusing on this subsample. In a second test, we limit the analysis to non-GIIPS banks. Again, while the economic significance decreases, the results remain qualitatively unchanged, as shown by Columns 5 and 6 .

Taken together, our findings suggest that the loan supply increase to low-IC ratio borrowers was indeed caused by zombie lending incentives of weakly capitalized banks.

The Online Appendix confirms that banks that remained weakly capitalized post-OMT indeed had incentives to "evergreen" loans to zombie borrowers by calculating for each bank what its regulatory capital ratio would have been if it had pulled the plug on these borrowers. Moreover, we test the robustness of our results with regard to two alternative measures of bank capitalization: (1) a continuous measure and (2) a measure that incorporates a capital adjustments required by the EBA for risky sovereign debt holdings. All results continue to hold.

\section{Real and Financial Outcomes}

To analyze whether there are differences between the behavior and performance of zombie and nonzombie firms pre- and post-OMT, we closely follow the approach in Acharya et al. (2018) and divide the financial information reported in Amadeus into the pre-OMT period (fiscal years 2009 to 2011) and the postOMT period (fiscal years 2012 to 2014). The indicator variable PostOMT is now equal to one if the financial information reported in Amadeus falls in the post-OMT period.

To proxy the extent to which firms benefited from the OMT announcement through their bank relationships, we construct the variable Indirect OMT windfall gain. First, we use the OMT windfall gain of each bank, as defined in Equation (1), and compute the average OMT windfall gain of all banks that act as lead arranger in a given syndicate. We denote this variable Average OMT windfall gain. Second, we calculate a firm's indirect gains from its lending relationships by weighting the Average OMT windfall gain of each of its loan syndicates by the fraction of its total outstanding syndicated loan amounts. This yields the following measure for firm $i$ in country $j$ in industry $h$ at time $t$ :

$$
\begin{aligned}
& \text { Indirect } O M T \text { windfall } \text { gain }_{i j h t}=
\end{aligned}
$$

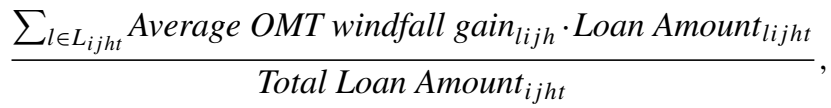

where $L_{i j h t}$ are all of the firm's loans outstanding at time $t .{ }^{38}$ We use five different measures for the firms' policies. In particular, we analyze changes in

38 We measure the dependence on banks that benefited from the OMT announcement as the average dependence on these banks over the 2009-2011 period. Results are qualitatively similar when using the 2006-2008 average. 
cash holdings $\left(\left(\right.\right.$ cash $_{t+1}-$ cash $\left._{t}\right) /$ total $\left._{\text {assets }}\right)$ and debt ((total liabilities ${ }_{t+1}-$ total liabilities $\left.)_{t}\right) /$ total $_{\text {assets }}$ ) to investigate changes in the firms' financial policies. To analyze nonfinancial firm policies, we consider employment growth ( $\triangle \log$ Employment), investment (CAPX/Tangible Assets), and the return on assets $(R O A)$.

We begin by exploring the effect of the OMT announcement on firm outcomes graphically. Figure 4 plots the time series of the cash holdings, leverage, employment growth, investment, and ROA, respectively, for high Indirect OMT windfall gain firms (i.e., firms with an above median Indirect OMT windfall gain), further split into high-IC ratio, low-IC ratio nonzombie, and zombie firms. The figure shows that low-IC ratio nonzombie firms significantly increased leverage and cash holdings post-OMT (panels A and B). Zombies, however, were not able to raise their cash holdings, despite the strong increase in leverage resulting from the inflow of new bank credit. Panels C-E show that none of the three firm groups show a significant increase in employment, investment, or ROA post-OMT. Moreover, the performance of zombie firms appears to be the worst of all firms.

To formally investigate whether borrowing firms with tight lending relationships to banks that benefited from the OMT announcement altered their corporate policies, we employ the following specification for firm $i$ in country $j$, and industry $h$ in year $t$ :

$$
\begin{aligned}
y_{i j h t+1}= & \beta_{1} \cdot \text { Indirect OMT windfall } \text { gain }_{i j h} \cdot \text { Post } O M T_{t} \\
& +\gamma \cdot X_{i j h t}+\text { Firm }_{i j h}+\text { Industry }_{h} \cdot \text { Country }_{j} \cdot \text { Year }_{t+1} \\
& +u_{i j h t+1} .
\end{aligned}
$$

Our baseline regression includes firm fixed effects, as well as firm-level control variables - firm size, leverage, net worth, the fraction of tangible assets, the IC ratio, and the EBITDA/total assets ratio - to capture other determinants of firms' corporate policies. ${ }^{39}$ Additionally, we include interactions between industry, year, and country fixed effects to capture unobserved time-varying shocks to an industry in a given country in a given year that may affect credit demand of borrowing firms as well as their real outcomes. Importantly, these fixed effects also absorb all shocks at the national level (changes in tax rates, regulations, etc.) that could affect investment and employment creation.

Table 6, panel A, presents the results for the full sample. A firm-year is the unit of observation. For ease of exposition, we only report the results for our key variable of interest, the interaction of Indirect OMT windfall gain with the PostOMT dummy. For the financial variables, we find a significant increase post-OMT in both cash and debt for the full sample of firms (Columns 1 and 2).

39 All results are qualitatively and quantitatively similar if we rerun these regressions using weighted least squares with firms' total assets as weights. 

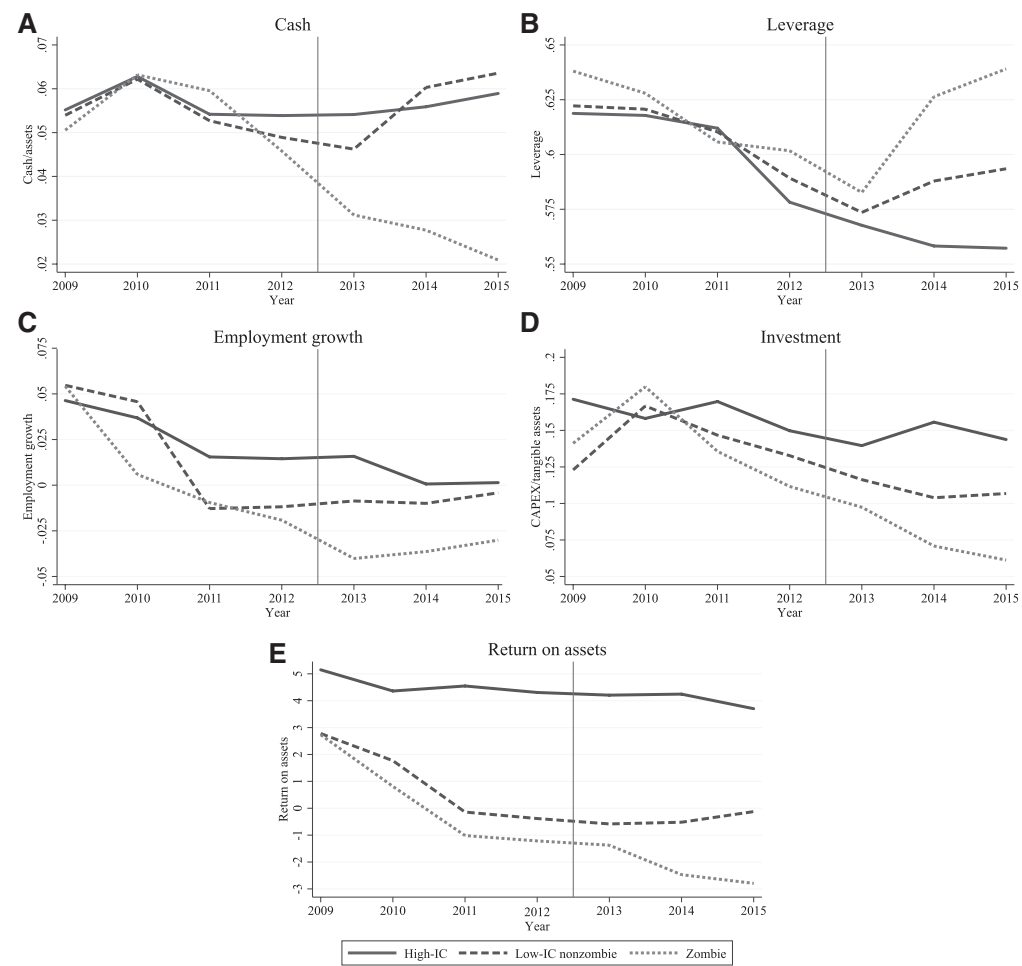

Figure 4

Financial and real effects

Panel A shows the evolution of the asset-weighted cash holdings as a fraction of total assets, and panel B shows the evolution of the asset-weighted leverage as a fraction of total assets. Panel C shows the evolution of the assetweighted employment growth rates; panel D shows the evolution of the asset-weighted capital expenditures as a fraction of tangible assets; and panel E shows the evolution of the asset-weighted return on assets. All panels show high Indirect $O M T$ windfall gain firms (i.e., firms with an above median Indirect OMT windfall gain), where we split these borrowers into three groups: High-IC ratio firms (blue-solid line), low-IC ratio nonzombie firms (red-dashed line), and zombie firms (green dotted line). A firm is classified as high-IC (low-IC) ratio firm if its 2009-2011 median IC ratio is above (below) the country-specific 2009-2011 median IC ratio. See the caption of Figure 2 for the definition of a zombie firm. The vertical line represents the OMT announcement period in 2012Q3.

The difference of the coefficients for the change in cash and the change in debt regressions is small and statistically insignificant (see Column 3). This result suggests that debt and cash holdings increased by a similar amount, implying that firms used the liquidity inflow from bank credit primarily to increase their cash reserves. This finding is consistent with the fact that we do not find any significant effects for the real variables. Neither employment nor investment or ROA (Columns 4-6) change significantly for firms with a high Indirect OMT windfall gain in the post-OMT period. Hence, the primary objective of firms on average seems to be regaining financial stability by increasing their cash reserves to precrisis levels. 
Table 6

Financial and real effects

A. All firms

\begin{tabular}{|c|c|c|c|c|c|c|}
\hline & $\begin{array}{c}(1) \\
\Delta \text { Cash }\end{array}$ & $\begin{array}{c}(2) \\
\Delta \text { Debt }\end{array}$ & $\begin{array}{c}(3) \\
\Delta \text { Cash- } \Delta \text { Debt }\end{array}$ & $\begin{array}{c}\text { (4) } \\
\text { Emp. growth }\end{array}$ & $\begin{array}{c}(5) \\
\text { CAPX }\end{array}$ & $\begin{array}{c}(6) \\
\text { ROA }\end{array}$ \\
\hline $\begin{array}{l}\text { Indirect OMT windfall gain } \\
\text { *PostOMT }\end{array}$ & $\begin{array}{l}0.315^{* *} \\
(2.54)\end{array}$ & $\begin{array}{l}0.316^{* *} \\
(2.36)\end{array}$ & $\begin{array}{l}-0.001 \\
(-0.01)\end{array}$ & $\begin{array}{r}0.061 \\
(0.62)\end{array}$ & $\begin{array}{l}-0.335 \\
(-1.07)\end{array}$ & $\begin{array}{r}0.014 \\
(0.04)\end{array}$ \\
\hline $\begin{array}{l}R^{2} \\
N\end{array}$ & $\begin{array}{c}.522 \\
5,324\end{array}$ & $\begin{array}{l}.605 \\
6,599\end{array}$ & & $\begin{array}{l}.804 \\
6,486\end{array}$ & $\begin{array}{l}.644 \\
6,492\end{array}$ & $\begin{array}{l}.587 \\
5,544\end{array}$ \\
\hline \multicolumn{7}{|l|}{ B. Quality classification 2009-2011 } \\
\hline $\begin{array}{l}\text { Indirect OMT windfall gain } \\
\text { *PostOMT } \\
\text { Indirect OMT windfall gain } \\
\text { *PostOMT*Low-IC }\end{array}$ & $\begin{array}{l}0.136 \\
(0.92) \\
0.574^{* * *} \\
(2.85)\end{array}$ & $\begin{array}{l}0.108 \\
(0.53) \\
0.579^{* *} \\
(2.09)\end{array}$ & $\begin{array}{l}-0.005 \\
(-0.00)\end{array}$ & $\begin{array}{r}-0.023 \\
(-0.17) \\
0.087 \\
(0.56)\end{array}$ & $\begin{array}{c}-0.092 \\
(-0.27) \\
-0.381 \\
(-0.83)\end{array}$ & $\begin{array}{r}0.185 \\
(0.53) \\
-0.498 \\
(-1.22)\end{array}$ \\
\hline $\begin{array}{l}R^{2} \\
N\end{array}$ & $\begin{array}{c}.550 \\
5,324\end{array}$ & $\begin{array}{l}.636 \\
6,599\end{array}$ & & $\begin{array}{l}.806 \\
6,486\end{array}$ & $\begin{array}{l}.644 \\
6,492\end{array}$ & $\begin{array}{l}.596 \\
5,544\end{array}$ \\
\hline \multicolumn{7}{|l|}{ C. Zombie firms } \\
\hline $\begin{array}{l}\text { Indirect OMT windfall gain } \\
\text { *PostOMT*Low-IC } \\
\text { Indirect OMT windfall gain } \\
\text { *PostOMT*Low-IC*Zombie }\end{array}$ & $\begin{array}{l}0.543^{* *} \\
(2.41) \\
-0.548^{* *} \\
(-2.02)\end{array}$ & $\begin{array}{l}0.541^{* *} \\
(2.50) \\
0.648^{* * *} \\
(2.86)\end{array}$ & $\begin{array}{l}0.002 \\
(0.01) \\
-1.196^{* * *} \\
(-3.38)\end{array}$ & $\begin{array}{c}0.030 \\
(0.32) \\
0.065 \\
(0.57)\end{array}$ & $\begin{array}{r}-0.194 \\
(-0.71) \\
0.007 \\
(0.01)\end{array}$ & $\begin{array}{l}-0.339 \\
(-1.45) \\
-0.255 \\
(-0.84)\end{array}$ \\
\hline $\begin{array}{l}R^{2} \\
N\end{array}$ & $\begin{array}{c}.574 \\
5,324\end{array}$ & $\begin{array}{l}.625 \\
6,599\end{array}$ & & $\begin{array}{l}.772 \\
6,486\end{array}$ & $\begin{array}{l}.592 \\
6,492\end{array}$ & $\begin{array}{l}.516 \\
5,544\end{array}$ \\
\hline $\begin{array}{l}\text { Mean dependent variable } \\
\text { SD dependent variable }\end{array}$ & $\begin{array}{l}0.010 \\
0.064\end{array}$ & $\begin{array}{r}-0.005 \\
0.065\end{array}$ & & $\begin{array}{l}0.014 \\
0.07\end{array}$ & $\begin{array}{l}0.141 \\
0.175\end{array}$ & $\begin{array}{l}0.035 \\
0.091 \\
\end{array}$ \\
\hline $\begin{array}{l}\text { Mean indirect OMT windfall gain } \\
\text { SD indirect OMT windfall gain }\end{array}$ & $\begin{array}{l}0.022 \\
0.032\end{array}$ & $\begin{array}{l}0.022 \\
0.032\end{array}$ & & $\begin{array}{l}0.022 \\
0.032\end{array}$ & $\begin{array}{l}0.022 \\
0.032\end{array}$ & $\begin{array}{l}0.022 \\
0.032\end{array}$ \\
\hline $\begin{array}{l}\text { Firm-level controls } \\
\text { Firm fixed effects } \\
\text { Industry-country-year fixed effects }\end{array}$ & $\begin{array}{l}\text { Yes } \\
\text { Yes } \\
\text { Yes }\end{array}$ & $\begin{array}{l}\text { Yes } \\
\text { Yes } \\
\text { Yes }\end{array}$ & & $\begin{array}{l}\text { Yes } \\
\text { Yes } \\
\text { Yes }\end{array}$ & $\begin{array}{l}\text { Yes } \\
\text { Yes } \\
\text { Yes }\end{array}$ & $\begin{array}{l}\text { Yes } \\
\text { Yes } \\
\text { Yes }\end{array}$ \\
\hline
\end{tabular}

Table 6 presents firm-level regression results. The dependent variables are the change in cash holdings, change in leverage, employment growth, investments, and ROA, respectively. In panel B, a firm is classified as high-IC (low-IC) ratio firm if its 2009-2011 median IC ratio is above (below) the country-specific 2009-2011 median IC ratio. Indirect OMT windfall gain measures the firms' indirect gains on sovereign debt holdings through their lenders, that is, for each firm, we measure the exposure it has to the value increase in the sovereign debt holdings of the banks from which it received loans. PostOMT is an indicator variable equal to 1 starting at the end of fiscal year 2012 and 0 before. See the caption of Figure 2 for the definition of a zombie firm. Firm control variables include the logarithm of total assets, leverage, tangibility, IC ratio, EBITDA as a fraction of total assets, and net worth. All firm-level control variables are lagged by one period. Standard errors are adjusted for heteroscedasticity and clustered at the firm level. $t$-statistics are reported in parentheses. ${ }^{*} p<0.10 ; * * p<0.05$; $* * * * 0.01$

In panel $\mathrm{B}$ of Table 6 , we provide evidence on the relation between financial and real effects and the Indirect OMT windfall gain of firms classified based on their median IC ratio during the sovereign debt crisis (2009 to 2011). Recall that Table 3, panel C, shows that primarily low-IC firms benefited from the loan volume expansion induced by the post-OMT value appreciation of the banks' sovereign debt holdings. Consistent with this evidence, the general picture that emerges from Table 6, panel B, is that the financial effects (i.e., increase in cash holdings and leverage) are driven by low-IC firms, whereas neither high- nor 
low-IC firms show a significant relation between Indirect OMT windfall gain and real economic activity like employment and investment.

Moreover, Table 6, panel $\mathrm{C}$, documents that zombies did not use their newly acquired credit to build cash reserves. For these firms, debt increased significantly more than cash holdings (Columns 1 and 2). A potential explanation is that these firms needed the liquidity to service interest payments on other existing loans. Consistent with this explanation, zombies only have an IC ratio of 0.23 , implying that they are unable to service interest payments from earnings alone.

Finally, there are no significant effects of the increased loan supply on employment, investment, or ROA (Columns 4-6) for zombie firms, suggesting no improvement in economic activity. ${ }^{40}$ The fact that the performance of zombie firms remained poor even after banks increased their loan supply is further evidence for zombie lending and against the firm balance sheet channel.

\section{Long-Run Effects and Market Distortions}

Next, we analyze the long-run effects of zombie lending and whether it led to market distortions. First, we track the amount of NPLs of banks that engaged in zombie lending behavior and the long-run default propensity of zombie compared to nonzombie firms. Second, we determine the spillover effects of the increased zombie prevalence for nonzombie firms.

\subsection{Long-run effects}

6.1.1 Banks. Figure 5, panel A, shows that for zombie lending banks, that is, banks that we identify as having extended an above-median share of zombie loans based on our syndicated loan data, the total NPLs/loans ratio (i.e., NPLs across all loan categories, not just syndicated loans) increased significantly in our sample period. In contrast, the NPLs/loans ratio for banks for which we do not find much evidence for zombie lending, shows only a slight increase. This suggests that zombie lending banks extended zombie loans also in other loan categories (e.g., loans to SMEs).

This graphical evidence is confirmed by the regression results presented in panel A of Table 7, where we formally compare the change in the banks' NPLs/total loans ratios from pre- to post-2014. ${ }^{41}$ The results shows that for

40 As noted by the Financial Times, this raises the concern " $[\ldots]$ that these companies - which spend so much of their cash servicing interest payments that they are unable to invest in new equipment or future growth areas could be at least partly to blame for the weak recovery in Europe, hogging resources that could go to more productive areas." See Stothard (2013).

41 We take the average of this ratio in 2012-2013 and 2014-2015, respectively. 

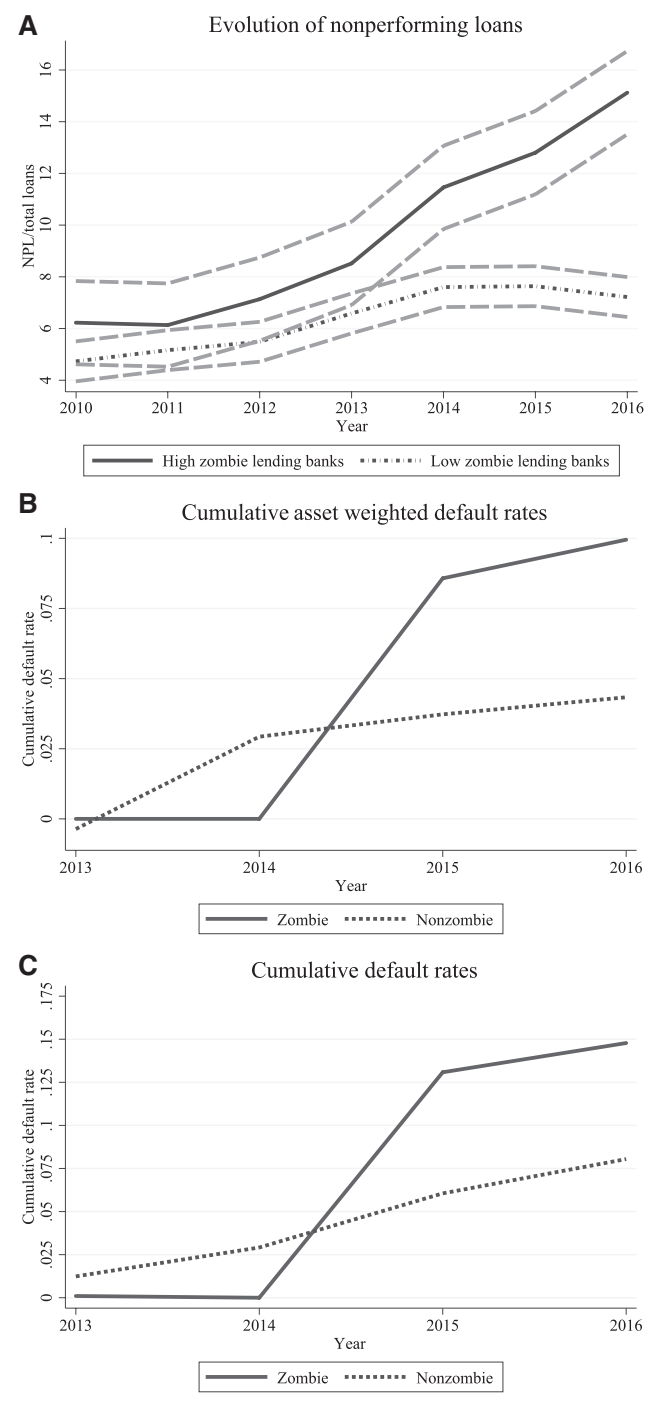

\section{Figure 5}

Evolution of nonperforming loans and firm default rates

Panel A shows the asset-weighted fraction of NPLs to total loans (in \%) for high and low zombie lending banks by the end of year $t$. The gray-dashed lines show 95\% confidence intervals. A bank is classified as high (low) zombie lending bank if it has an above (below) median fraction of zombie loans/total assets. Panel B presents asset-weighted cumulative firm default rates, and panel $\mathrm{C}$ presents equally weighted cumulative firm default rates for zombie (blue-solid line) and nonzombie (red-dashed line) firms by the end of year $t$. See the caption of Figure 2 for the definition of a zombie firm.

banks with zombie lending incentives (i.e., weakly capitalized banks with high OMT windfall gains), the NPLs/loans ratio increased significantly, while it did not change for well-capitalized banks. 
Table 7

Long-run effects

A. Nonperforming loans

\begin{tabular}{|c|c|c|c|c|}
\hline & $\begin{array}{c}(1) \\
\Delta \text { NPL }\end{array}$ & $\begin{array}{c}(2) \\
\Delta \text { NPL }\end{array}$ & $\begin{array}{c}(3) \\
\Delta \mathrm{NPL}\end{array}$ & $\begin{array}{c}(4) \\
\Delta \mathrm{NPL}\end{array}$ \\
\hline OMT windfall gain & $\begin{array}{c}0.149 \\
(0.76)\end{array}$ & $\begin{array}{c}0.128 \\
(0.61)\end{array}$ & $\begin{array}{c}0.227 \\
(1.26)\end{array}$ & $\begin{array}{c}0.045 \\
(0.29)\end{array}$ \\
\hline Weakly capitalized & $\begin{array}{l}0.017^{* *} \\
(2.20)\end{array}$ & $\begin{array}{l}0.016^{*} \\
(2.05)\end{array}$ & $\begin{array}{c}0.012 \\
(1.32)\end{array}$ & $\begin{array}{l}-0.002 \\
(-0.22)\end{array}$ \\
\hline OMT windfall gain*Weakly capitalized & $\begin{array}{l}0.980^{* *} \\
(2.85)\end{array}$ & $\begin{array}{l}1.014^{* *} \\
(2.75)\end{array}$ & $\begin{array}{l}0.792^{* *} \\
(2.48)\end{array}$ & $\begin{array}{l}0.714^{* *} \\
(2.76)\end{array}$ \\
\hline $\log$ (Assets) & & $\begin{array}{l}-0.001 \\
(-0.90)\end{array}$ & $\begin{array}{l}0.000 \\
(0.12)\end{array}$ & $\begin{array}{c}0.002 \\
(0.28)\end{array}$ \\
\hline RWA/TA & & & $\begin{array}{c}0.068^{*} \\
(1.91)\end{array}$ & $\begin{array}{l}0.153^{\text {** }} \\
(2.91)\end{array}$ \\
\hline$R^{2}$ & 0.594 & 0.595 & 0.632 & 0.771 \\
\hline$N$ & 49 & 49 & 49 & 49 \\
\hline Country fixed effects & No & No & No & Yes \\
\hline \multicolumn{5}{|l|}{ B. Firm defaults } \\
\hline & Default & Default & Default & \\
\hline Low-IC & $\begin{array}{l}0.026^{* * *} \\
(4.03)\end{array}$ & $\begin{array}{l}0.024^{* * *} \\
(3.60)\end{array}$ & $\begin{array}{l}0.029^{* * *} \\
(3.58)\end{array}$ & \\
\hline Zombie & $\begin{array}{l}-0.036^{* * *} \\
(-3.11)\end{array}$ & $\begin{array}{l}-0.034^{* * *} \\
(-2.77)\end{array}$ & $\begin{array}{l}-0.054^{*} \\
(-1.88)\end{array}$ & \\
\hline Zombie*Post & $\begin{array}{l}0.059^{* *} \\
(2.11)\end{array}$ & $\begin{array}{l}0.059^{* *} \\
(1.98)\end{array}$ & $\begin{array}{l}0.070^{* *} \\
(2.00)\end{array}$ & \\
\hline Low-IC*Post & $\begin{array}{c}0.002 \\
(0.43)\end{array}$ & $\begin{array}{c}0.004 \\
(0.97)\end{array}$ & $\begin{array}{c}0.000 \\
(0.02)\end{array}$ & \\
\hline $\begin{array}{l}R^{2} \\
N\end{array}$ & $\begin{array}{c}.067 \\
4,993\end{array}$ & $\begin{array}{c}.085 \\
4,993\end{array}$ & $\begin{array}{c}.195 \\
4,993\end{array}$ & \\
\hline Industry fixed effects & Yes & No & No & \\
\hline Country fixed effects & Yes & No & No & \\
\hline Time fixed effects & Yes & No & No & \\
\hline Industry-time fixed effects & No & Yes & No & \\
\hline Country-time fixed effects & No & Yes & No & \\
\hline Industry-country-time fixed effects & No & No & Yes & \\
\hline
\end{tabular}

Panel A presents cross-sectional bank regressions. The dependent variable is the change of a bank's NPLs to total loans ratio (average post- minus average pre-2014). OMT windfall gain is the value gain on banks' sovereign debt holdings as a fraction of total equity. Weakly capitalized is a dummy variable that equals 1 if a bank is less than $2 \%$ above the regulatory capital requirement post-OMT. Panel B presents firm panel regressions for the years 2012-2016. Post is an indicator variable equal to 1 starting at the end of fiscal year 2015 and 0 before. We classify a firm as defaulted if it is either no longer active or if insolvency proceedings have been opened. A firm is classified as high-IC (low-IC) ratio firm if its 2009-2011 median IC ratio is above (below) the country-specific 2009-2011 median IC ratio. For the definition of a zombie firm see the caption of Figure 2. Standard errors are clustered at the country of bank level in panel A and at the firm level in panel B. $t$-statistics are reported in parentheses. Significance levels: $* p<0.10 ; * * p<0.05 ; * * * p<0.01$.

6.1 .2 Firms. Next, we track whether the rise in NPLs is followed by a subsequent default propensity increase for zombies. For this analysis, we collect data on firm defaults from Amadeus and augment this information with an extensive news search on default events for our sample firms (see the Online Appendix for more details). We classify a firm as defaulted if it either entered bankruptcy or if insolvency proceedings have been opened. Figure 5, panel $\mathrm{B}$, presents asset-weighted cumulative default rates separately for zombie and 
nonzombie firms, and panel $\mathrm{C}$ shows equally weighted rates. The first 2 years post-OMT (i.e., in 2013 and 2014), zombies had a similar or even smaller default propensity than nonzombie firms. This result is remarkable as zombie firms are on average of much lower quality than nonzombie firms (see Table 4, panel B). However, the liquidity provided through zombie loans allowed many zombies to stay afloat (the intended purpose of these loans in the first place). Yet, starting in 2015, we see a sharp default rate increase for zombies, which is consistent with the rise in NPLs starting a year earlier.

To formally test whether the sharp default rate increase for zombies is also statistically significant, we run panel regressions for the post-OMT period until 2016. The dependent variable in these regressions is an indicator variable for whether a firm defaulted in year $t$. The results in Table 7, panel B, show that low-IC ratio firms in general have a higher default probability than high-IC ratio firms. Moreover, consistent with the evidence from panels $\mathrm{B}$ and $\mathrm{C}$ of Figure 5, zombie firms have a lower default propensity than other low-IC ratio firms immediately post-OMT (2012-2014) but a significantly higher default probability during 2015-2016.

\subsection{Zombie distortions}

Nonzombie firms could have been negatively affected by the prevalence of zombies through two potential channels. First, banks with zombie lending incentives shift their lending toward existing borrowers that struggle to service their debt. This credit misallocation leads to a loan supply reduction and higher interest rates for productive, creditworthy firms operating in the same industry. Hence, these firms are potentially more financially constrained than firms in industries without such loan supply distortions.

Second, the zombie prevalence might lead to distorted market competition, which also negatively affects nonzombie firms competing in the same industries. The normal competitive outcome would be that impaired firms reduce employment and lose market share. But, zombie loans keep distressed borrowers artificially alive, which congests the respective markets. The resultant distorting effects on healthy firms in the same industries include, for example, depressed product market prices and increased market wages by hanging on to the workers whose productivity in the zombie firms declined. Because of these two channels, we expect that a high prevalence of congesting zombies in a particular industry resulted in larger distortions for healthy firms and thus a less vigorous recovery in these industries compared to industries with a low zombie prevalence (see also Caballero, Hoshi, and Kashyap 2008).

We start by providing suggestive country-industry-level evidence of the distortions caused by the increased zombie prevalence. Similar in spirit to Caballero, Hoshi, and Kashyap (2008), we compare the average industry productivity for industries with a large and small increase in the zombie fraction. We follow Caballero, Hoshi, and Kashyap (2008) and measure productivity as $\log ($ Sales $)-2 / 3 * \log ($ Employment $)-1 / 3 * \log ($ Fixed Assets). Figure A6 shows 
that the productivity decreased in industries that faced a larger zombie increase post-OMT, whereas industries with a lower zombie increase experienced a productivity increase. This result is confirmed by the cross-sectional regressions at the country-industry level in Table A13. The table shows that industries with a larger zombie increase post-OMT had a significantly lower productivity growth, measured as average growth in the industry productivity from the pre-OMT period (2009-2011) to the post-OMT period (2012-2015).

To test whether a high zombie presence had negative spillover effects on nonzombie firms operating in the same industry, we estimate the following panel regression:

$$
\begin{aligned}
y_{i j h t+1}= & \beta_{1} \cdot \text { Nonzombie }_{i j h t} \\
& +\beta_{2} \cdot \text { Nonzombie }_{i j h t} \cdot \text { Industry Frac Zombie }_{j h t} \\
& +\gamma \cdot X_{i j h t}+\text { Firm }_{i j h}+\text { Industry }_{h} \cdot \text { Country }_{j} \cdot \text { Year }_{t+1} \\
& +u_{i j h t+1},
\end{aligned}
$$

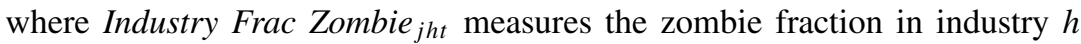
(SIC2) in country $j$ at time $t$ and the dependent variables are the interest rate, employment growth, investment, and productivity. ${ }^{42}$ Our coefficient of interest is $\beta_{2}$, that is, whether nonzombie firms pay higher interest rates, invest less, have lower employment growth, or a higher average productivity due to a high zombie prevalence in their industry. We again include firm and industry-country-year fixed effects. The latter alleviate concerns that the zombie prevalence in an industry in a given country and year is correlated with its overall performance. Moreover, if industry-specific policies by the government were time-varying, this specification would control for the changes. ${ }^{43}$

Table 8, panel A, presents the results for this regression analysis. The results show that nonzombie firms pay higher interest rates $\left(\beta_{2}>0\right)$, invest less $\left(\beta_{2}<0\right)$, have lower employment growth rates $\left(\beta_{2}<0\right)$, and higher average productivity $\left(\beta_{2}>0\right)$ if they operate in industries with many zombie firms compared to firms in industries with a low zombie prevalence. Regarding the average productivity result, as argued by Caballero, Hoshi, and Kashyap (2008), if nonzombie firms have to reduce their business because of competitive distortions, they primarily cut projects with a low productivity, which increases their average productivity.

The estimates in Table 8, Column 2 imply that nonzombie firms with an average increase in their industry's zombie fraction (which was $7 \mathrm{pp}$ ) invested around $12.6 \%$ of capital less post-OMT compared to a scenario in which the

42 We use the universe of very large Amadeus firms to calculate the industry fraction of zombies because the competitive general equilibrium effects work in the aggregate through the full sample of firms receiving zombie credit.

43 Hence, the only shocks that would bias our results are shocks correlated with Industry Frac Zombie and that differently affect zombie and nonzombie firms within the same industry. 
Table 8

Externalities

A. Entire sample

\begin{tabular}{|c|c|c|c|c|}
\hline & $\begin{array}{c}\text { (1) } \\
\text { Int. payment }\end{array}$ & $\begin{array}{c}\text { (2) } \\
\text { CAPX }\end{array}$ & $\begin{array}{c}\text { (3) } \\
\text { Emp. growth }\end{array}$ & $\begin{array}{c}\text { (4) } \\
\text { Productivity }\end{array}$ \\
\hline Industry frac zombie*Nonzombie & $\begin{array}{l}0.024^{* * *} \\
(2.97)\end{array}$ & $\begin{array}{l}-0.018^{* *} \\
(-2.03)\end{array}$ & $\begin{array}{l}-0.008^{* * *} \\
(-2.99)\end{array}$ & $\begin{array}{l}0.008^{* *} \\
(2.32)\end{array}$ \\
\hline $\begin{array}{l}R^{2} \\
N\end{array}$ & $\begin{array}{l}.825 \\
5,574\end{array}$ & $\begin{array}{c}.572 \\
5,070\end{array}$ & $\begin{array}{c}.504 \\
4,280\end{array}$ & $\begin{array}{c}.935 \\
4,932\end{array}$ \\
\hline \multicolumn{5}{|l|}{ B. Competitive industries } \\
\hline Industry frac zombie $*$ Nonzombie & $\begin{array}{l}0.032^{* * * *} \\
(3.43)\end{array}$ & $\begin{array}{l}-0.021^{* *} \\
(-2.47)\end{array}$ & $\begin{array}{l}-0.009^{* * *} \\
(-2.92)\end{array}$ & $\begin{array}{l}0.010^{* *} \\
(2.56)\end{array}$ \\
\hline $\begin{array}{l}R^{2} \\
N\end{array}$ & $\begin{array}{l}.836 \\
2,800\end{array}$ & $\begin{array}{c}.589 \\
2,511\end{array}$ & $\begin{array}{c}.572 \\
2,057\end{array}$ & $\begin{array}{c}.957 \\
2,421\end{array}$ \\
\hline \multicolumn{5}{|l|}{ C. Noncompetitive industries } \\
\hline Industry frac zombie*Nonzombie & $\begin{array}{l}0.025^{*} \\
(1.95)\end{array}$ & $\begin{array}{l}-0.008 \\
(-1.15)\end{array}$ & $\begin{array}{l}-0.001 \\
(-0.46)\end{array}$ & $\begin{array}{c}0.002 \\
(1.07)\end{array}$ \\
\hline $\begin{array}{l}R^{2} \\
N\end{array}$ & $\begin{array}{l}.852 \\
2,774\end{array}$ & $\begin{array}{c}.617 \\
2,559\end{array}$ & $\begin{array}{c}.656 \\
2,133\end{array}$ & $\begin{array}{c}.926 \\
2,511\end{array}$ \\
\hline \multicolumn{5}{|c|}{ D. External finance-dependent industries } \\
\hline Industry frac zombie*Nonzombie & $\begin{array}{l}0.029^{* * *} \\
(3.20)\end{array}$ & $\begin{array}{l}-0.020^{* * *} \\
(-2.84)\end{array}$ & $\begin{array}{l}-0.009^{* *} \\
(-2.11)\end{array}$ & $\begin{array}{l}0.008^{* *} \\
(2.35)\end{array}$ \\
\hline $\begin{array}{l}R^{2} \\
N\end{array}$ & $\begin{array}{l}.821 \\
3,032\end{array}$ & $\begin{array}{c}.583 \\
2,857\end{array}$ & $\begin{array}{c}.521 \\
2,343\end{array}$ & $\begin{array}{r}.920 \\
2,618\end{array}$ \\
\hline \multicolumn{5}{|c|}{ E. Nonexternal finance-dependent industries } \\
\hline Industry frac zombie $*$ Nonzombie & $\begin{array}{l}0.018^{*} \\
(1.84)\end{array}$ & $\begin{array}{l}-0.003 \\
(-1.30)\end{array}$ & $\begin{array}{l}-0.001 \\
(-1.45)\end{array}$ & $\begin{array}{c}0.002 \\
(1.25)\end{array}$ \\
\hline $\begin{array}{l}R^{2} \\
N\end{array}$ & $\begin{array}{l}.832 \\
2,542\end{array}$ & $\begin{array}{c}.553 \\
2,213\end{array}$ & $\begin{array}{l}.544 \\
1,937\end{array}$ & $\begin{array}{l}.950 \\
2,314\end{array}$ \\
\hline $\begin{array}{l}\text { Firm-level controls } \\
\text { Firm fixed effects } \\
\text { Industry-country-year fixed effects }\end{array}$ & $\begin{array}{l}\text { Yes } \\
\text { Yes } \\
\text { Yes }\end{array}$ & $\begin{array}{l}\text { Yes } \\
\text { Yes } \\
\text { Yes }\end{array}$ & $\begin{array}{l}\text { Yes } \\
\text { Yes } \\
\text { Yes }\end{array}$ & $\begin{array}{l}\text { Yes } \\
\text { Yes } \\
\text { Yes }\end{array}$ \\
\hline
\end{tabular}

This table presents firm-level regressions. The dependent variables are interest payments, investments, employment growth, and productivity, respectively. Industry frac zombie measures the asset-weighted fraction of zombie firms in a given industry and country in a given year (measured using the universe of very large Amadeus firms). Nonzombie is an indicator variable equal to 1 for firms not classified as zombie firms. See the caption of Figure 2 for the definition of a zombie firm. To measure the competitiveness of an industry, we use the Herfindahl-Hirschman index (HHI) and split our sample at the median in competitive and noncompetitive industries (panels B and C). To determine an industry's dependence on external finance, we follow Rajan and Zingales (1998) and Acharya and Xu (2017) and consider an industry to be external finance dependent if the median fraction of capital expenditures not financed through internal cash flows of the firms in this industry is above the median of all industries (panels D and E). Firm control variables include the logarithm of total assets, leverage, tangibility, IC ratio, EBITDA as a fraction of total assets, and net worth. Standard errors are adjusted for heteroscedasticity and clustered at the firm level. $t$-statistics are reported in parentheses. $* p<0.10 ; * * p<0.05$; $* * * p<0.01$.

zombie fraction would have stayed at its pre-OMT level. An industry at the 95th percentile experienced a zombie increase of $18 \mathrm{pp}$, implying that nonzombie firms invested around $32 \%$ of capital less due to the zombie increase. When looking at employment growth (Column 3), we find that firms that experienced an average zombie fraction increase in their industry had around $5.6 \mathrm{pp}$ lower 
Table 9

Effects on nonzombie firms

A. Investment loss

\begin{tabular}{|c|c|c|c|c|}
\hline Industry & $\begin{array}{c}\text { Avg. } \\
\text { Investment } \\
(\% \text { of capital })\end{array}$ & $\begin{array}{c}\Delta \text { Fraction } \\
\text { Zombie }\end{array}$ & $\begin{array}{c}\text { investment } \\
\text { loss } \\
\text { (\% of capital) }\end{array}$ & $\begin{array}{c}\text { Investment } \\
\text { years lost }\end{array}$ \\
\hline Construction & 9.48 & $13.59 \mathrm{pp}$ & 24.4 & 2.6 \\
\hline Manufacturing & 11.4 & $5.50 \mathrm{pp}$ & 9.9 & 0.9 \\
\hline Trade & 10.8 & $9.79 \mathrm{pp}$ & 17.6 & 1.6 \\
\hline Service & 11.1 & $9.28 \mathrm{pp}$ & 16.8 & 1.5 \\
\hline Other & 10.6 & $3.99 \mathrm{pp}$ & 7.1 & 0.7 \\
\hline \multicolumn{5}{|c|}{ B. Employment loss } \\
\hline Industry & $\begin{array}{l}\text { Avg. emp. } \\
\text { growth (\%) }\end{array}$ & $\begin{array}{l}\Delta \text { Fraction } \\
\text { zombie }\end{array}$ & $\begin{array}{c}\text { Employment } \\
\text { loss }\end{array}$ & \\
\hline Construction & -2.1 & $13.59 \mathrm{pp}$ & $10.8 \mathrm{pp}$ & \\
\hline Manufacturing & 0.55 & $5.50 \mathrm{pp}$ & $4.4 \mathrm{pp}$ & \\
\hline Trade & 0.24 & $9.79 \mathrm{pp}$ & $7.8 \mathrm{pp}$ & \\
\hline Service & -1.0 & $9.28 \mathrm{pp}$ & $7.4 \mathrm{pp}$ & \\
\hline Other & 0.5 & $3.99 \mathrm{pp}$ & $3.1 \mathrm{pp}$ & \\
\hline
\end{tabular}

Panels A and B present estimates of the investment and employment losses, respectively, that result from the increased presence of zombie firms in an industry. See the caption of Figure 2 for the definition of a zombie firm. The estimates are derived from a partial equilibrium analysis that compares the outcomes from the de facto fraction of zombie firms to an outcome if the fraction of zombie firms had stayed at its pre-OMT level.

employment growth rates. Considering again the 95th percentile, we find that nonzombie firms in this industry had $14.4 \mathrm{pp}$ lower employment growth rates.

Table 9 provides an overview of the evolution of the fraction of zombie firms by sector for GIIPS countries. The average zombie fraction increase was largest in the construction sector with an increase of $13.59 \mathrm{pp}$. As panel A shows, given an average investment to capital rate of $9.48 \%$ in this sector, the rise in the zombie fraction implies an investment loss of $24.4 \%$ or the equivalent of 2.6 years of investment. Similarly, striking numbers can be found in the trade industry, where 1.6 investment years were lost. Panel B shows that the increase in zombie firms translated into an employment loss of $10.8 \mathrm{pp}$ in the construction industry and a loss of $7.8 \mathrm{pp}$ in the trade industry.

Finally, we investigate whether these distortionary effects are disproportionately larger in industries with certain baseline characteristics. In particular, we analyze whether these negative externalities were more intense in competitive versus noncompetitive industries and in external finance-dependent versus nondependent industries.

To measure an industry's competitiveness, we use the Herfindahl-Hirschman index (HHI) and split our sample at the median in competitive and noncompetitive industries. The results in Table 8, panels $\mathrm{B}$ and $\mathrm{C}$, show that, due to a loan supply shift to zombie firms, nonzombie firms had to pay higher interest rates if the zombie prevalence in their industry was particularly high, irrespective of the industry's competitiveness. Yet only nonzombie firms in competitive industries suffered real effects from a high zombie prevalence (i.e., lower investments and employment growth). 
To determine an industry's dependence on external finance, we follow Rajan and Zingales (1998) and Acharya and Xu (2017) and consider an industry to be external finance dependent if its firms' median fraction of capital expenditures not financed through internal cash flows is above the median of all industries. Table 8, panels D and E, show that, while again all nonzombie firms suffered higher interest rates when facing a large zombie presence, only nonzombie firms in external finance-dependent industries experienced negative real effects from a high zombie prevalence.

Finally, we employ two placebo tests to address concerns that other shocks on the real economic activity at the national level (changes in the corporate tax rate, regulations, etc.) might affect our results. First, Table A12, panel A, shows that there is no significant relation between randomly (across industry-country pairs) assigned Industry Frac Zombie and the firms' real economic activity. Second, panels B and C show that, while Industry Frac Zombie does not have a significant effect on the firms' real outcomes pre-OMT, there is a significant effect post-OMT.

Another potential concern with our zombie distortions analysis is that the Stable-Unit-Treatment-Value-Assumption (SUTVA, see Rubin 1978) could be violated due to spillover effects between industries, which would bias our estimates. ${ }^{44}$ In particular, as banks only have a finite amount of credit to allocate among industries, industries that are not directly affected by zombie lending could still suffer a lower credit supply as lending is shifted toward zombie industries. If the SUTVA is violated due to this spillover, our estimated effect of a zombie prevalence increase for nonzombie firms would be biased downward as the average treatment on the treated effect would be higher than the estimated difference between treatment and control group.

\section{Conclusion}

In this paper, we show that the OMT announcement improved the health of banks in the periphery of the eurozone. By increasing the prices of periphery sovereign bonds, banks holding these assets realized significant windfall gains, and this improved their capitalization. On the aggregate level, this bank health improvement translated into an increased loan supply to the corporate sector. However, these loans were mainly extended to low-quality borrowers with whom the respective banks already had a preexisting lending relationship. We show that this lending pattern was mainly caused by zombie lending motives of banks that regained some lending capacity post-OMT but remained weakly capitalized. These undercapitalized banks had an incentive to evergreen loans to their struggling borrowers to avoid having to declare outstanding loans nonperforming.

\footnotetext{
44 The SUTVA implies that treatments received by one unit do not affect outcomes for another unit.
} 
We find that nonzombie firms that regained access to bank financing postOMT used the cash inflow from new loans primarily to build cash reserves. In contrast, zombie firms that received new loans only used a fraction of the cash inflow to build cash reserves, likely spending the rest on interest payments on outstanding loans. Finally, neither zombie nor nonzombie firms showed a significant increase in real activity, that is, an increase in employment or investment. Over time, zombie firms experienced greater default rates and weakly capitalized banks that we identify as banks that engaged in zombie lending suffered a stronger increase in nonperforming loans.

Finally, we find that, due to credit misallocation and the resultant market distortions, creditworthy firms were negatively affected if they operated in industries with a high zombie prevalence. Both their employment growth and investments were lower than that of nonzombie firms in industries without a zombie problem.

More broadly, our paper shows that central banks can indirectly recapitalize their banking sector by influencing the prices of assets that banks hold in their portfolios. By increasing the value of these assets banks can realize significant windfall gains and this improves their equity positions. However, authorities need to pay close attention to the magnitude of these gains. If the gains are too low to adequately recapitalize (some) banks, zombie lending incentives might arise as banks that remain weakly capitalized have an incentive to evergreen loans to troubled firms. This can lead to significant market distortions in industries with a high zombie firm prevalence.

Our analysis thus highlights the importance of a well-capitalized banking sector for an effective transmission of unconventional monetary policy measures (such as the OMT) to the real economy. While the OMT program helped to avert a collapse of the eurozone by stabilizing sovereign bond yields and (partially) restoring financial stability, combining the program with a targeted recapitalization program and/or forced bank closures would most likely have induced a stronger economic recovery. Instead, low bank capitalization and uncertainty about the health of the banks' balance sheets remain significant issues as evidenced by the malaise in the Italian banking sector 3 years postOMT, where $19 \%$ of loans are classified as nonperforming. As noted by the Financial Times, "the growing fear is that the continent could be following the path of Japan, where low interest rates, looser government policy and the failure of the big banks to foreclose on unprofitable and highly indebted companies is thought to have contributed to two decades of weak growth." 45

\section{References}

Acharya, V., and Z. Xu. 2017. Financial dependence and innovation: The case of public versus private firms. Journal of Financial Economics 124:223-43.

45 See Stothard (2013). 
Acharya, V. V., T. Eisert, C. Eufinger, and C. Hirsch. 2018. Real effects of the sovereign debt crisis in Europe: Evidence from syndicated loans. Review of Financial Studies 31:2855-96.

Acharya, V. V., B. Imbierowicz, S. Steffen, and D. Teichmann. 2015. Does the lack of financial stability impair the transmission of monetary policy? Working Paper.

Acharya, V. V., D. Pierret, and S. Steffen. 2015. Lender of last resort versus buyer of last resort - evidence from the European sovereign debt crisis. Working Paper.

Acharya, V. V., and S. Steffen. 2015. The greatest carry trade ever? Understanding eurozone bank risks. Journal of Financial Economics 115:215-36.

Agarwal, S., S. Chomsisengphet, N. Mahoney, and J. Stroebel. 2017. Do banks pass through credit expansions to consumers who want to borrow? Quarterly Journal of Economics 133:129-90.

Aiyar, S., A. Banerji, B. Barkbu, W. Bergthaler, P. Berkmen, J. Bluedorn, J. Garrido, A. Jobst, J. John, K. Kang, T. Kinda, H. Lin, Y. Liu, D. Monaghan, M. Moretti, S. Saksonovs, H. Schoelermann, and T. Wu. 2015. IMF: Euro Area Policies. Policy Paper.

Aiyar, S., C. W. Calomiris, J. Hooley, Y. Korniyenko, and T. Wieladek. 2014. The international transmission of bank capital requirements: Evidence from the UK. Journal of Financial Economics 113:368-82.

Aiyar, S., C. W. Calomiris, and T. Wieladek. 2014. Does macro-prudential regulation leak? Evidence from a UK policy experiment. Journal of Money, Credit and Banking 46:181-214.

2016. How does credit supply respond to monetary policy and bank minimum capital requirements? European Economic Review 82:142-65.

Altavilla, C., D. Giannone, and M. Lenza. 2014. The financial and macroeconomic effects of OMT announcements. International Journal of Central Banking 12:29-57.

Bassett, W., S. Demiralp, and N. Lloyd. 2017. Government support of banks and bank lending. Journal of Banking \& Finance. Advance Access published July 29, 2017, 10.1016/j.jbankfin.2017.07.010.

Berg, T., A. Saunders, and S. Steffen. 2015. The total cost of corporate borrowing in the loan market: Don't ignore the fees. The Journal of Finance 71:1357-92.

Berg, T., A. Saunders, S. Steffen, and D. Streitz. 2016. Mind the gap: The difference between U.S. and European loan rates. Review of Financial Studies 30:948-87.

Berger, A. N., C. H. Bouwman, T. Kick, and K. Schaeck. 2016. Bank liquidity creation following regulatory interventions and capital support. Journal of Financial Intermediation 26:115-41.

Berger, A. N., T. Makaew, and R. A. Roman. 2018. Do borrowers benefit from bank bailouts? The effects of TARP on loan contract terms. Financial Management. Advance Access published April 10, 2018, 10.1111/fima.12222.

Bernanke, B. S., and M. Gertler. 1995. Inside the black box: The credit channel of monetary policy transmission. The Journal of Economic Perspectives 9:27-48.

Black, L. K., and L. N. Hazelwood. 2013. The effect of TARP on bank risk-taking. Journal of Financial Stability 9:790-803.

Blattner, L., L. Farinha, and F. Rebelo. 2017. When losses turn into loans: The cost of undercapitalized banks. Working Paper.

Brei, M., L. Gambacorta, and G. Von Peter. 2013. Rescue packages and bank lending. Journal of Banking \& Finance 37:490-505.

Brunnermeier, M. K., and Y. Sannikov. 2016. The I theory of money. Working Paper.

Caballero, R. J., T. Hoshi, and A. K. Kashyap. 2008. Zombie lending and depressed restructuring in Japan. American Economic Review 98:1943-77.

Carpinelli, L., and M. Crosignani. 2017. The effect of central bank liquidity injections on bank credit supply. Working Paper. 
Chakraborty, I., I. Goldstein, and A. MacKinlay. 2016. Monetary stimulus and bank lending. Working Paper.

Crosignani, M., M. Faria-e Castro, and L. Fonseca. 2015. The (unintended?) consequences of the largest liquidity injection ever. Working Paper.

Daetz, S. L., M. G. Subrahmanyam, D. Y. Tang, and S. Q. Wang. 2016. Did ECB liquidity injections help the real economy? Working Paper.

Degryse, H., O. De Jonghe, S. Jakovljevic, K. Wang, Mulier, and G. Schepens. 2017. Identifying credit supply shocks with bank-firm data: Methods and applications. Working Paper.

Dell'Ariccia, G., L. Laeven, and R. Marquez. 2014. Real interest rates, leverage, and bank risk-taking. Journal of Economic Theory 149:65-99.

Di Maggio, M., A. Kermani, and C. Palmer. 2016. How quantitative easing works: Evidence on the refinancing channel. Working Paper.

Diamond, D. W. 1991. Monitoring and reputation: The choice between bank loans and directly placed debt. Journal of Political Economy 99:689-721.

Duchin, R., and D. Sosyura. 2014. Safer ratios, riskier portfolios: Banks' response to government aid. Journal of Financial Economics 113:1-28.

ECB. 2012. Verbatim of the remarks made by Mario Draghi. Speech at the Global Investment Conference in London, July 26. https://www.ecb.europa.eu/press/key/date/2012/html/sp120726.en.html.

ECB. 2014. Verbatim of the remarks made by Mario Draghi. Speech at the Frankfurt European Banking Congress Frankfurt am Main, November 21. https://www.ecb.europa.eu/press/key/date/2014/html/sp141121.en.html.

Economist. 2013a. Blight of the living dead. Economist, July 13. https://www.economist.com/ leaders/2013/07/13/blight-of-the-living-dead.

Economist. 2013b. Europe's other debt crisis. Economist, October 26. https://www.economist.com/ leaders/2013/10/24/europes-other-debt-crisis.

Ferrando, A., A. Popov, and G. F. Udell. 2018. Do SMEs benefit from unconventional monetary policy and how? Micro-evidence from the eurozone. Journal of Money, Credit and Banking. Advance Access published November 28, 2018, 10.1111/jmcb.12581.

Giannetti, M., and A. Simonov. 2013. On the real effects of bank bailouts: Micro evidence from Japan. American Economic Journal: Macroeconomics 5:135-67.

Gropp, R., T. Mosk, S. Ongena, and C. Wix. 2019. Bank response to higher capital requirements: Evidence from a quasi-natural experiment. Review of Financial Studies 32:266-99.

Heider, F., F. Saidi, and G. Schepens. Forthcoming. Life below zero: Bank lending under negative policy rates. Review of Financial Studies.

Jassaud, N., and M. K. Kang. 2015. A strategy for developing a market for nonperforming loans in Italy. Working Paper.

Jiménez, G., S. Ongena, J.-L. Peydró, and J. Saurina. 2014. Hazardous times for monetary policy: What do twenty-three million bank loans say about the effects of monetary policy on credit risk-taking? Econometrica 82:463-505.

2017. Macroprudential policy, countercyclical bank capital buffers, and credit supply: Evidence from the Spanish dynamic provisioning experiments. Journal of Political Economy 125:2126-77.

Kalemli-Ozcan, S., B. Sorensen, C. Villegas-Sanchez, V. Volosovych, and S. Yesiltas. 2015. How to construct nationally representative firm level data from the ORBIS Global Database. Working Paper.

Kandrac, J., and B. Schlusche. 2016. Quantitative easing and bank risk taking: Evidence from lending. Working Paper.

Kane, E. J. 1989. The S\&L Insurance mess: How did it happen? Report. The Urban Institute, Washington, DC. 
Khwaja, A. I., and A. Mian. 2008. Tracing the impact of bank liquidity shocks: Evidence from an emerging market. American Economic Review 98:1413-42.

Krishnamurthy, A., S. Nagel, and A. Vissing-Jorgensen. 2018. ECB policies involving government bond purchases: Impact and channels. Review of Finance 22:1-44.

Li, L. 2013. TARP funds distribution and bank loan supply. Journal of Banking \& Finance 37:4777-92.

Lin, Y., X. Liu, and A. Srinivasan. 2014. Unintended effects of the TARP program: Evidence from relationship borrowers of the TARP recipient banks. Working Paper.

Maddaloni, A., and J.-L. Peydró. 2011. Bank risk-taking, securitization, supervision, and low interest rates: Evidence from the euro-area and the US lending standards. Review of Financial Studies 24:2121-65.

Peek, J., and E. S. Rosengreen. 2005. Unnatural selection: Perverse incentives and the allocation of credit in Japan. American Economic Review 95:1144-66.

Rajan, R., and L. Zingales. 1998. Financial dependence and growth. American Economic Review 88:559-86.

Rodnyansky, A., and O. M. Darmouni. 2017. The effects of quantitative easing on bank lending behavior. Review of Financial Studies 30:3858-87.

Rubin, D. B. 1978. Bayesian inference for causal effects: The role of randomization. Annals of Statistics 6:34-58.

Standard \& Poor's. 2010. A guide to the European loan market. New York: McGraw-Hill.

Stothard, M. 2013. Companies: The rise of the zombie. Financial Times, January 8. https://www.ft.com/content/7c93d87a-58f1-11e2-99e6-00144feab49a.

Sufi, A. 2007. Information asymmetry and financing arrangements: Evidence from syndicated loans. Journal of Finance 62:629-68.

Szczerbowicz, U. 2015. The ECB unconventional monetary policies: Have they lowered market borrowing costs for banks and governments? International Journal of Central Banking 11:91-127.

UBI Banca. 2012. Annual Report 2012 - Separate Financial Report. https://www.ubibanca.it/ contenuti/RigAlle/2012\%20Separate\%20Financial\%20Report.pdf.

Veronesi, P., and L. Zingales. 2010. Paulson's gift. Journal of Financial Economics 97:339-68.

Wall Street Journal. 2012. Europe Banks Fear a Flight. Wall Street Journal, May 21. https://www.wsj.com/articles/SB10001424052702304019404577416200222787714. 